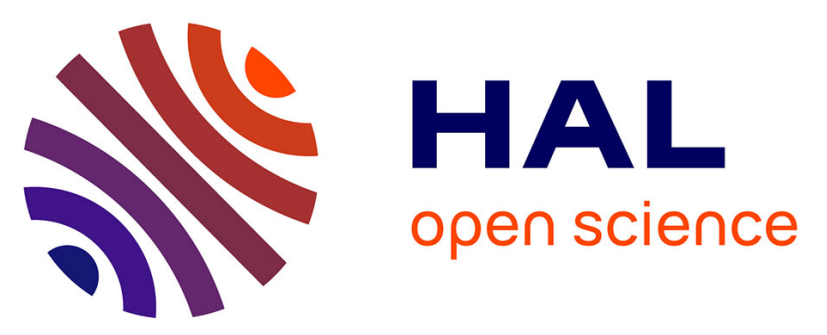

\title{
Petrophysical properties of volcanic rocks and impacts of hydrothermal alteration in the Guadeloupe Archipelago (West Indies)
}

Vivien Navelot, Yves Géraud, Alexiane Favier, Marc Diraison, Michel Corsini, Jean-Marc Lardeaux, Chrystele Verati, Jeanne Mercier de Lepinay, Lucie Legendre, Gildas Beauchamps

\section{To cite this version:}

Vivien Navelot, Yves Géraud, Alexiane Favier, Marc Diraison, Michel Corsini, et al.. Petrophysical properties of volcanic rocks and impacts of hydrothermal alteration in the Guadeloupe Archipelago (West Indies). Journal of Volcanology and Geothermal Research, 2018, 360, pp.1-21. 10.1016/j.jvolgeores.2018.07.004 . hal-02457291

\section{HAL Id: hal-02457291 \\ https://hal.univ-lorraine.fr/hal-02457291}

Submitted on 14 Jun 2020

HAL is a multi-disciplinary open access archive for the deposit and dissemination of scientific research documents, whether they are published or not. The documents may come from teaching and research institutions in France or abroad, or from public or private research centers.
L'archive ouverte pluridisciplinaire HAL, est destinée au dépôt et à la diffusion de documents scientifiques de niveau recherche, publiés ou non, émanant des établissements d'enseignement et de recherche français ou étrangers, des laboratoires publics ou privés. 


\title{
Petrophysical Properties of Volcanic Rocks and Impacts of Hydrothermal Alteration in the Guadeloupe Archipelago (West Indies)
}

\author{
Vivien Navelot $^{\mathrm{a}^{*}}$, Yves Géraud ${ }^{\mathrm{a}}$, Alexiane Favier ${ }^{\mathrm{b}, \mathrm{c}}$, Marc Diraison ${ }^{\mathrm{a}}$, Michel Corsini ${ }^{\mathrm{b}}$, Jean- \\ Marc Lardeaux ${ }^{\mathrm{b}}$, Chrystèle Verati ${ }^{\mathrm{b}}$, Jeanne Mercier de Lépinay ${ }^{\mathrm{d}}$, Lucie Legendre ${ }^{\mathrm{c}}$, Gildas \\ Beauchamps ${ }^{\mathrm{e}}$ \\ ${ }^{a}$ Université de Lorraine, UMR 7359 GeoRessources, Ecole Nationale Supérieure de Géologie, 2 Rue du Doyen Marcel Roubault, Vandoeuvre-lès- \\ Nancy 54500, France \\ ${ }^{b}$ Université Côte d'Azur, CNRS - Observatoire de la Côte d'azur - IRD - UMR 7329 Géoazur, 250 Rue Albert Einstein, Valbonne 06560, France \\ ${ }^{c}$ Université des Antilles, UMR 5243 Geosciences Montpellier, Campus de Fouillole, Pointe à Pitre 97159, Guadeloupe, France \\ ${ }^{d}$ Université de Strasbourg, Institut de Physique du Globe de Strasbourg, UMR 7516 CNRS, 5 Rue René Descartes, Strasbourg 67084, France \\ ${ }^{e}$ Université de Cergy Pontoise, Laboratoire Géosciences et Environnement Cergy, 1 Rue Descartes, Neuville-sur-Oise 95000, France
}

\section{Abstract}

The GEOTREF project aims at developing high enthalpy geothermal energy in fractured reservoirs. It focuses on active volcanic islands and especially on the Basse-Terre Island (Guadeloupe archipelago). As part of this project we measured several petrophysical properties to better understand how fluids flow in the hydrothermal system, provide a set of parameters to modelers and build dataset for the future interpretation of well logs. The thermo-physical rock properties: bulk and grain density, porosity, permeability, compressional wave velocity, thermal conductivity and diffusivity and finally specific heat capacity of outcropping volcanic rocks from Guadeloupe archipelago (Lesser Antilles) were measured and a dataset was built. According to field observation, samples were gathered into three lithological classes and then separated by degree of alteration thanks to macroscopic aspect and optical microscopy. Geochemical data were obtained, and magnetic minerals identified combining AMS and variation of magnetic susceptibility with temperature.

Investigated lithotypes are lava flows, debris flows and pyroclastics gathering ash, pumice and scoria deposits. For lavas and debris flows, three degrees of alteration were defined: fresh, slightly to moderately altered and highly hydrothermalized. Only fresh pyroclastics were studied because the altered state was not outcropping.

Samples are typically of andesite composition and belong to tholeiitic and calc-alkaline series. Porosity of lavas consists in high density cooling joints and vesicles of different shapes whereas pores in debris flows and pyroclastics are located both between and into particles. Median porosities and permeabilities are clearly

\footnotetext{
* Corresponding author at: UMR 7359 GeoRessources, Ecole Nationale Supérieure de Géologie. 2 Rue du Doyen Marcel Roubault - BP 10162. 54505 Vandoeuvre-lès-Nancy cedex
} 
distinct for lavas $\left(4 \%\right.$ and $\left.6.10^{-18} \mathrm{~m}^{2}\right)$, debris flows $\left(33 \%\right.$ and $\left.4.10^{-14} \mathrm{~m}^{2}\right)$ and pyroclastics $\left(34 \%\right.$ and $8.10^{-13}$ $\left.\mathrm{m}^{2}\right)$. The porosity difference implies a thermal conductivity twice to three times higher for lavas $\left(1.68 \mathrm{~W} . \mathrm{m}^{-}\right.$ $\left.{ }^{1} \cdot \mathrm{K}^{-1}\right)$. Specific heat capacity is close for all lithothypes $\left(0.75-0.97 \mathrm{~kJ} \cdot \mathrm{kg}^{-1} \cdot \mathrm{K}^{-1}\right)$.

Advancing hydrothermal alteration removes magnetic minerals and transforms initial rocks by replacing initial plagioclases and pyroxenes in neoformed chlorite, white micas, quartz, epidote and clay minerals modifying the shape of pore network. Hydrothermal alteration results in a reduction of pore throat diameters. It tends to decrease petrophysical differences between lavas and debris flows increasing porosity and permeability of effusive rocks while the opposite effects are observed in debris flows. 
Geothermal exploitation in magmatic - volcanic fields where convection dominates heat transfer is well developed (Moeck, 2014). Such fields exist above subduction areas like in the western pacific area (Heise et al., 2016; McNamara et al., 2016; Mielke et al., 2016; Ratouis and Zarrouk, 2016; Wilmarth and Stimac, 2015). This geological context is favorable because it is associated with a strong heat flux. Active subduction occurs in the Atlantic Ocean, along the Caribbean archipelago (Fig. 1a). The geothermal potential of Caribbean is proved, and several sites are in the prospecting phase (Bertani, 2016). Currently, only the Bouillante field (Guadeloupe Island) is operating. Seven exploratory and production wells were drilled for its development (Bézèlgues-Courtade and Bes-de-Berc, 2007). After forty years of exploration and production, the understanding of the Bouillante geothermal system is still limited due to the high complexity of its geological context. The structural framework and location of fluid flow pathways are well defined (Calcagno et al., 2012). The composition of hydrothermal fluid is well documented (Bouchot et al., 2008; Iundt and Ouzounian, 1985; Sanjuan et al., 2010, 2004, 2001, 2000; Sanjuan and Brach, 1998; Traineau et al., 2014). However, origins of fluid and heat are still under debate. Only few data have been published and conceptual models for fluid flow remain weak (Lachassagne et al., 2009; Lopez et al., 2011), as well as the geometry of the reservoir (Bouchot et al., 2010, 2008).

There is a clear lack of petrological, thermal and physical data on volcanic rocks of Guadeloupe in contrast with other islands in the Caribbean where geothermal energy is not developed yet (e.g. Martinique (Bernard, 1999; Bernard et al., 2007)). Therefore, it is difficult to identify the targeted volcanic formations and what are the impacts of hydrothermal alteration on rocks. As part of the exploration and development of high enthalpy geothermal energy in the Vieux-Habitants area (Fig. 1c), characterization of petrophysical properties of rocks in different degrees of hydrothermal alteration is performed to develop geothermal reservoir models. To do this, outcrop analogue studies were led and a comprehensive set of fresh or hydrothermally altered outcropping rocks was collected. These analogue studies provide important information on geobody size and geometry (Howell et al., 2014). They are also a cheap way to investigate petrophysical properties on a large set of samples. Outcrop studies are commonly used for geothermal exploration (Aretz et al., 2015; Lenhardt and Götz, 2015, 2011). Previous reservoir characterizations were led on similar rocks in several areas like New Zealand (Cant et al., 2018; Mielke et al., 2016, 2015; Siratovich et al., 2014), Philippines (Stimac et al., 2004), Faroe Islands (Ólavsdóttir et al., 2015) and Mexico (Lenhardt and Götz, 2011). These studies performed both 
on samples from outcrops and cores provided large datasets of petrophysical properties providing data to constrain numerical models with real measured properties. Overall, they highlighted: 1 - a decrease of porosity and permeability with increasing depth; 2 - a decrease of porosity associated with hydrothermal alteration which result in an increase of thermal conductivity and 3 - better matrix porosity and permeability for breccia and pyroclastics than lava.

Studied samples come from Basse-Terre Island (Basal, Complex, Northern Chain and Vieux-HabitantsBouillante area) and Terre-de-Haut Island (Figs. 1b-f). In this paper, the study aims at characterizing petrophysical properties of matrix for lava flows, debris flows and pyroclastics to build a database, improve the interpretation of forthcoming borehole logging, understand how fluids flow in the different lithological classes and provide parameters for static and dynamic 3D reservoir models. These properties have been measured both on fresh rocks coming from Vieux-Habitants-Bouillante area and older exhumed rocks of the Basal Complex and Terre-de-Haut which could have been buried in the same thermal and pressure conditions as rocks of the currently exploited Bouillante geothermal field. Indeed, the central part of Terre-de-Haut was defined as an exhumed geothermal system by Verati et al. (2016). The volcanic activity of the Basal Complex occurred coevally with Terre-de-Haut (Zami et al., 2014). We can suppose that the Basal Complex was buried before its exhumation and placed at a relatively high temperature according to abnormally high geothermal gradient calculated in this area (Manga et al., 2012). Objectives of the data set are: 1 - Provide petrophysical properties on matrix of pyroclastics and debris flows and not only concentrate on lava blocks (Bernard, 1999; Bernard et al., 2007); 2 - define the role of hydrothermal alteration and weathering on the petrography, the microstructure, and their resulting petrophysical properties; 3 - identify contribution of the different lithotypes on the reservoir geometry. Based on a first exploratory mission we decided to focus only on two islands: Terrede-Haut and Basse-Terre that are approximately in the same geodynamic context and have a similar volcanic activity. 


\section{Geological context}

The Guadeloupe archipelago is located at the convergent boundary between the North American and Caribbean plates (Fig. 1a). This convergence is accommodated by the subduction of the North and South American lithospheres under the Caribbean plate at a relatively low velocity of approximately $2 \mathrm{~cm} . \mathrm{yr}^{-1}$ (DeMets et al., 2000; Symithe et al., 2015). This subduction produced two successive volcanic arcs (Bouysse, 1983). The outer older volcanic arc was active from Eocene to Early Miocene. It comprises several islands e.g. Grande-Terre of Guadeloupe, Marie-Galante and Petite-Terre (Fig. 1b), topped by Pliocene to Holocene carbonates platforms (Munch et al., 2014) and eastern Martinique (Bouysse and Westercamp, 1990). The inner volcanic arc began its activity during the Pliocene and is still active. It gathers several islands like Saint Kitts and Nevis, Dominica or Montserrat. Some of these islands have a well-known seismic activity and historical eruptions (Feuillet et al., 2010, 2002). Three islands of the Guadeloupe archipelago belong to the recent volcanic arc (Bouysse and Westercamp, 1990): Terre-de-Bas and Terre-de-Haut in Les Saintes archipelago and Basse-Terre with the active volcano of La Soufrière (Figs $1 \mathrm{~b}$ and $\mathrm{c}$ ). The activity of the Grande Découverte-Soufrière Complex is a major human safety issue especially since the last major eruption in 1976 even if it was only limited to a seismic crisis and a phreatic eruption (Komorowski et al., 2005). Therefore a lot of studies brought out a large amount of geological, geochemical and geophysical data on this wellmonitored volcano (e.g. Coutant et al., 2012; Gaudin et al., 2016, 2015, 2013; Lesparre et al., 2016; Pozzi et al., 1979; Rosas-Carbajal et al., 2016; Samper et al., 2009). Moreover, the recent offshore seismic activity between Les Saintes and Dominica relaunched studies on the structural framework of the archipelago (Bazin et al., 2010; Escartín et al., 2016; Feuillet et al., 2011; Leclerc et al., 2016, 2014). 


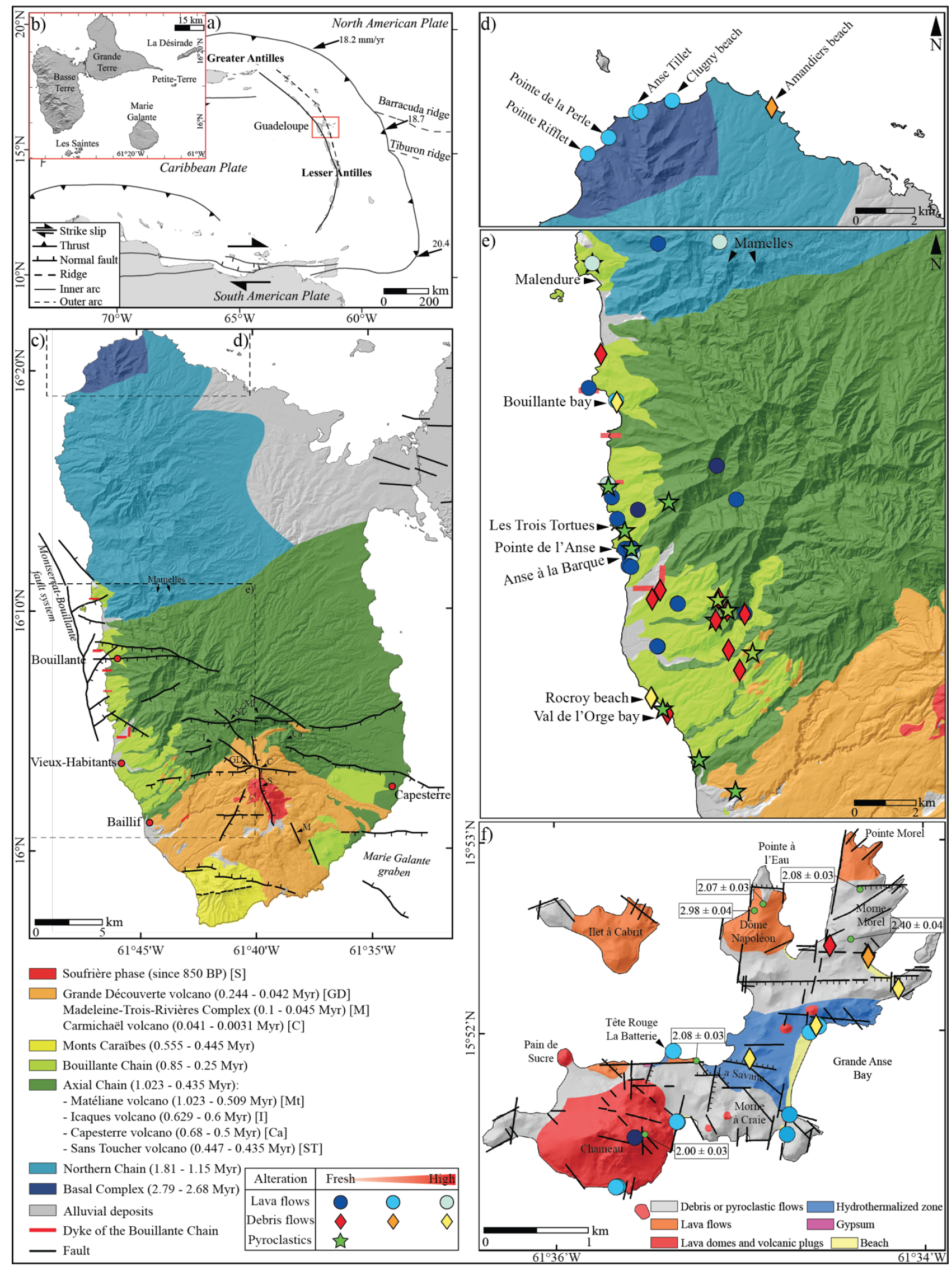


Fig. 1. a) Geodynamic setting of the Lesser Antilles arc (modified from Bouysse and Westercamp, 1990; Feuillet et al., 2002; Symithe et al., 2015). b) The Guadeloupe archipelago. $5 \mathrm{~m}$ resolution DEM from IGN (Institut national de l'information géographique et forestière). c) Simplified geological map of Basse-Terre Island with major volcanic complexes and structures (Boudon, 1988; Mathieu, 2010). Groundmass K/Ar ages from Blanc, 1983; Carlut et al., 2000; Ricci et al., 2015b, 2015a, 2017; Samper et al., 2007, 2009. Major faults from Calcagno et al., 2012; Feuillet et al., 2002; Leclerc et al., 2016. d and e) Location map of studied samples with the different rock types and their degree of alteration: d) Basal Complex in the northern part of Basse-Terre Island; e) Vieux-Habitants-Bouillante area. f) Location of studied samples and simplified geological map of Terre-de-Haut with the dominant lithotypes in each area. Tectonic sketch map of the main faults. Modified from Jacques and Maury (1988a) and Verati et al. (2016) according to field observations. KAr ages (Myr) are from Zami et al., 2014. (COLOR FOR ONLINE AND PRINT VERSIONS / IMAGE SIZE: FULL PAGE)

\subsection{Geology of Basse-Terre Island}

Basse-Terre is a late Tertiary to Quaternary still active volcanic island that belongs to the inner arc of the Lesser Antilles. The island is made up of composite volcanoes built by spaced pulses of activity (Davidson and De Silva, 2000). It consists in six major eruptive complexes that are successively emplaced from north to south according to a NNW-SSE to NW-SE direction (Fig. 1c). However, several volcanic edifices and seamounts are located away from this general alignment and others do not enter in the progressive southward migration (Mathieu, 2010). The oldest volcanic complex is the Basal Complex outcropping in the northern part of the island. It was active between 2.79 \pm 0.04 Myr and 2.68 \pm 0.04 Myr (K-Ar ages, Samper et al. (2007)) and forms the substratum of Basse-Terre. It is made of sub-aerial lava flows and eroded volcanic edifices (Mathieu, 2010). The calc-alkaline Northern Chain, 1.81 \pm 0.03 Myr to $1.15 \pm 0.02$ Myr (K-Ar ages, Samper et al. (2007)), consists of voluminous lava flows and domes of andesitic and dacitic compositions (Komorowski et al., 2005). The Axial and Bouillante Chains composed of Piton Bouillante, Icaques, Capesterre and Sans Toucher volcanoes formed between 1.023 $\pm 0.025 \mathrm{Myr}$ and $0.435 \pm 0.008 \mathrm{Myr}(\mathrm{K}-\mathrm{Ar}$ ages, Samper et al. (2007)). These chains are characterized by voluminous hyaloclastites covered by lava flows. On the west coast, the volcanism activity is essentially phreatomagmatic and there is a wide range of magma compositions: olivine basalts, andesites, dacites and quartz-bearing rhyolites (Komorowski et al., 2005). The Monts Caraïbes were active from 0.555 Myr to 0.445 Myr (K-Ar ages, Samper et al. (2007)). The inactive Trois-Rivières-Madeleine Complex and still active Grande Découverte-Soufrière Complex are younger than 0.25 Myr (K-Ar ages, Samper et al. (2007)). They are characterized by an effusive activity, which produced voluminous domes, lava flows and a more limited volume of pyroclastics (block-and-ash flows, ash and scoria flows). 
Since the 1970's the geology of Guadeloupe archipelago is extensively studied in particular for its geothermal resource (Bouchot et al., 2011, 2010; Calcagno et al., 2012; Patrier et al., 2003; Sanjuan and Brach, $2015,1998)$. Indeed a high-temperature $\left(250-260^{\circ} \mathrm{C}\right)$ geothermal field has been identified in Bouillante (Fig. 1c) in the 1970's (Bouchot et al., 2010). This geothermal field is exploited since 1985 for electricity generation. Since 2005, this geothermal plant has a capacity of 15 MWe (Sanjuan and Traineau, 2008). The Bouillante geothermal field developed in a regional key geodynamic area located at the intersection of the major tectonic structures of the Lesser Antilles (Calcagno et al., 2012; Thinon et al., 2010) accommodating the oblique convergence between the Caribbean and North American plates. Two regional fault systems join in this area. The NW-SE Montserrat-Bouillante fault system is composed of several 'en echelon' oblique normal strike-slip faults that accommodate a sinistral motion. The ESE-WNW to E-W Bouillante-Capesterre normal fault system could be the western termination of the E-W Marie-Galante graben system.

\subsection{Geology of Terre-de-Haut Island}

Les Saintes archipelago including Terre-de-Haut Island represent the emerged part of a plateau largely covered by plio-quaternary reef carbonates (Andreieff et al., 1979). Terre-de-Haut Island is entirely composed of medium-K calc-alkaline andesite rocks (Jacques et al., 1984; Zami et al., 2014). This composition is typical of the central part of the recent active arc in the Lesser Antilles. The volcanic activity in Terre-de-Haut began approximately at the same time as in Basse-Terre (Samper, 2007). Three volcanic phases, between $2.98 \pm 0.04$ Myr and 2.00 \pm 0.03 Myr, built Terre-de-haut (Jacques et al., 1984; Jacques and Maury, 1988b, 1988a; Zami et al., 2014). Phase I, at $2.98 \pm 0.04 \mathrm{Myr}$ (K-Ar ages), consists of dacitic lava flows and explosive breccia from Napoléon dome (Fig. 1f). The second phase, at $2.40 \pm 0.04 \mathrm{Myr}$, built up the Morne Morel, starting with explosive phreato-magmatic activity and continuing with the emplacement of pyroclastic flows. The third phase, from 2.08 $\pm 0.03 \mathrm{Myr}$ to $2.00 \pm 0.03 \mathrm{Myr}$, achieved the build-up of the island with the development of the Pointe Morel basic andesitic flows associated with the phreato-magmatic deposit and the dark andesite lava flow with two pyroxenes in the central part of Terre-de-Haut. This phase ended with the emplacement of the Chameau dome and several other intrusions. The central part of Terre-de-Haut is affected by high hydrothermal alteration that limits dating of this area since rocks are totally transformed (Fig. 1f). Verati et al. (2016) characterized this area as an exhumed geothermal system and described paragenesis associated with hydrothermal alteration. 


\subsection{Hydrothermal alteration}

Hydrothermal alteration in the central part of Terre-de-Haut consists in the development of smectite, kaolinite, veins of quartz, pyrite and gypsum (Jacques and Maury, 1988a). Verati et al. (2016) specified the high temperature association. They observed a first high-temperature association composed of chlorite and epidote aggregates developed as pseudomorphs of primary magmatic clinopyroxenes and plagioclases. The second association consists in chlorite, serpentine and oxides aggregates developed at the expense of orthopyroxenes. Veins filled either by chalcedony, pyrite and quartz or chlorite, smectite and goethite aggregates recut these new minerals. The last association comes from an advanced argilitic alteration consisting in the development of kaolinite, illite and smectite (montmorillonite). High gypsum and pyrite contents are observed in the most altered areas. All of these elements match with a high-temperature hydrothermal paragenesis developed in an epithermal context (Patrier et al., 2013).

Verati et al. (2016) also demonstrated that the development of this highly hydrothermalized area is controlled by the intersection of two major normal fault systems N090-N110 and N130-140 (Fig. 1f), having approximately the same directions observed in the Bouillante geothermal field (Fig. 1c).

\section{Material and methods}

\subsection{Samples}

According field observations, we distinguished three major classes of rock types: lava flows, coarse breccia and pyroclastics. Breccia gather coarse and heterogeneous poorly sorted deposits like debris avalanches, debris flows and lahar. Coarse breccia are called further debris flows because it is the dominant brecciated rock type. Debris flows are composed of fine-grained matrix (clay to fine pebbles) supporting a significant content of cobbles and boulders. Pyroclastics gather fine grained indurated and homogeneous deposits containing ashes, pumices and scoria. Largest elements are decimeter size pumice. Lavas and debris flows may also be separated in three groups according their alteration degree. The objective is not to distinguish weathering and hydrothermal alterations but understand general impacts of alteration on petrophysical properties. Weathering and hydrothermal alteration are not separated but the difference is made between fresh, slightly to moderately altered and highly altered samples (Fig. 2). Fresh samples are the more numerous because altered samples are restricted to very limited areas (see Table 2 for repartition of samples by lithotypes). Only fresh pyroclastics were sampled because the altered states did not outcrop in studied areas. 
Alteration was defined firstly according macroscopic observations and secondly using a selection of representative thin sections. In order to be comprehensive, each outcropping lithological class was sampled.

Fresh samples were collected in the Vieux-Habitants-Bouillante area and in Terre-de-Haut Island. Samples with slight to moderate weathering and/or hydrothermal alteration were collected in the Basal Complex, the Northern Chain, the Bouillante Chain and Terre-de-Haut Island. Finally, the highly hydrothermalized samples were collected in Mamelles massif and in the exhumed geothermal system of Terre-de-Haut (Figs. 1d, e and f).
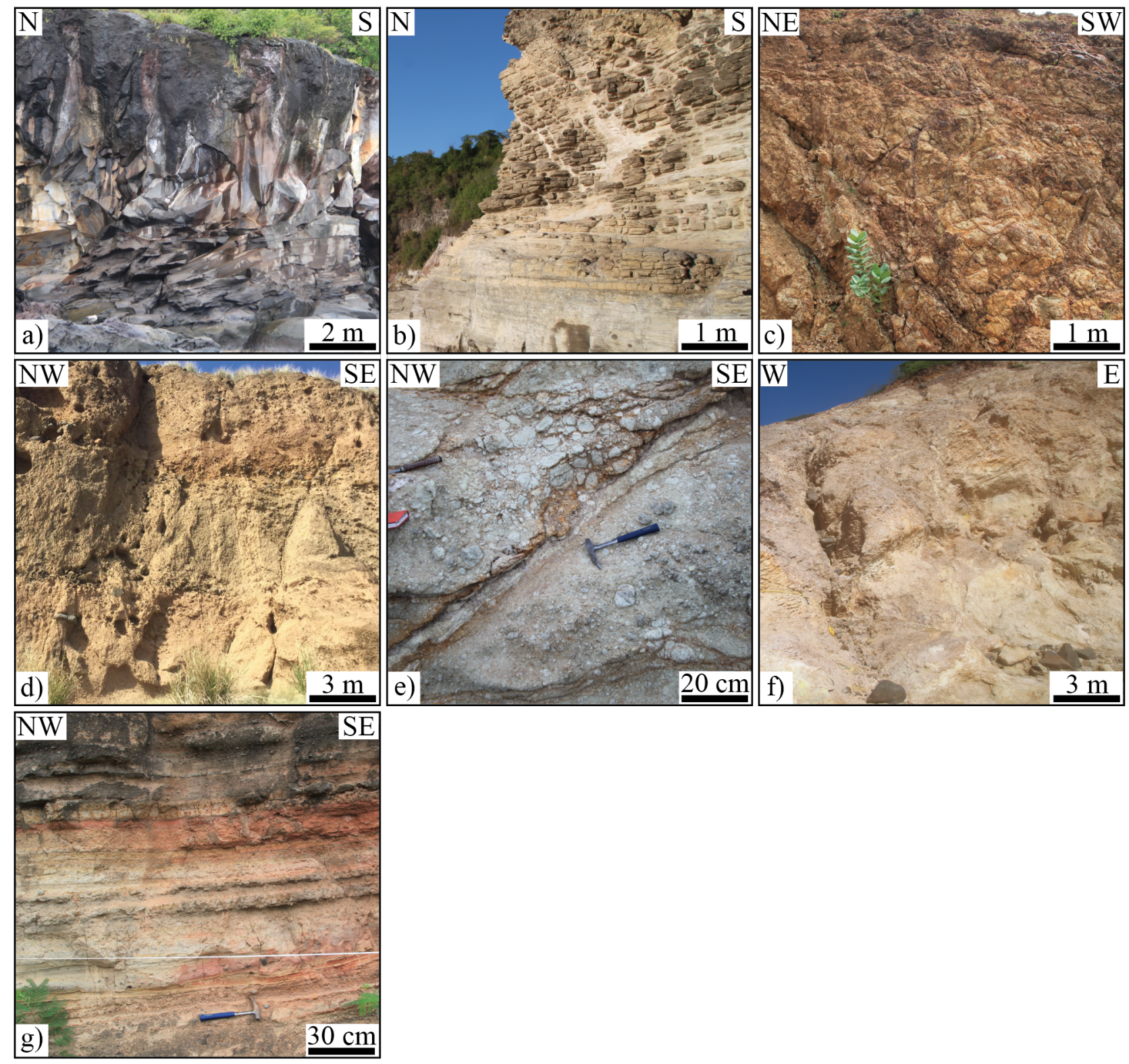

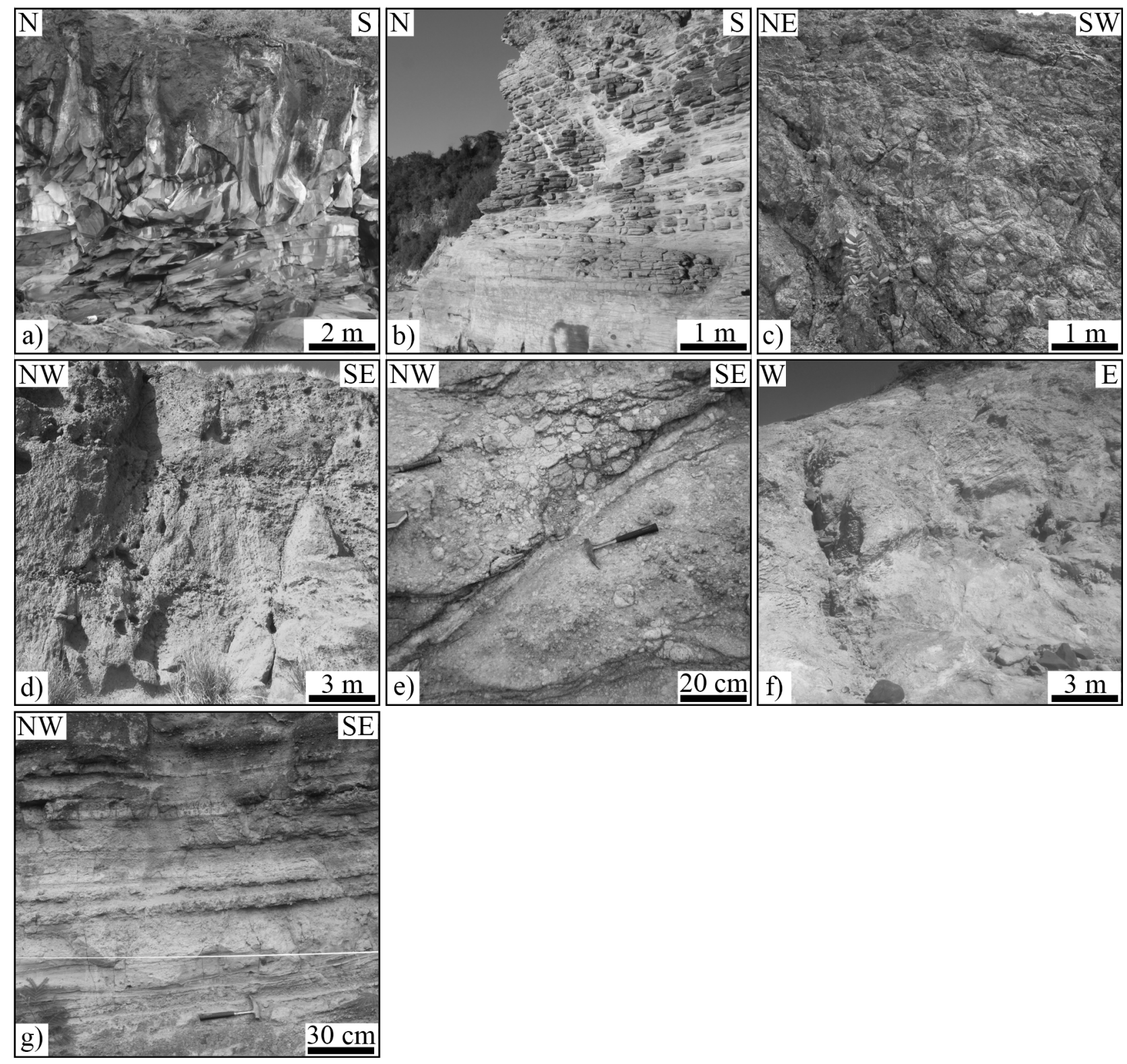

Fig. 2. The seven lithotypes. Lava flows are on the first line: a) fresh lava flow from Les Trois Tortues (location Fig. 1e); b) moderately hydrothermalized lava flow from Anse Tillet (Fig. 1d); c) highly hydrothermalized lava flow in La Savane (Fig. 1 f). Coarse volcano sedimentary deposits are represented in the second line: d) coarse debris flow from the Val de l'Orge bay (Fig. 1e); e) moderately hydrothermalized debris flow from the Amandiers beach (Fig. 1d) and f) highly hydrothermalized debris flow from Grande Anse Bay (Fig. 1f). g) Pyroclastics from Les Trois Tortues (COLOR FOR ONLINE VERSION ONLY / IMAGE SIZE: FULL PAGE)

Samples were taken directly on outcrops as oriented blocks. Parallelepipeds were cut to measure magnetic susceptibility, P-wave velocity, thermal conductivity and diffusivity. For lavas, the size of parallelepipeds is consistent with the spacing of cooling joints. For pyroclastics and debris flows, the limits of samples are not constrained by fractures or cooling joints and cutting cubes is easier. Size of blocks is comprised between 4 to $10 \mathrm{~cm}$ in thickness and approximately $10 \mathrm{~cm}$ both for length and width. $25 \mathrm{~mm}$ diameter plugs were drilled to perform porosity, permeability and density measurements (see section 4.2.2 for representativeness). For coarse 
debris flows, physical measurements on plugs were limited to matrix because the size of cobbles and boulders notably exceeds the capacity of measuring instruments.

Surfaces of friable blocks were flattened, and porosity measurements were done on pieces of rocks with similar size of plugs. Every sample was dried in an oven until a constant weight is obtained before performing measurements. The drying temperature was set to $60^{\circ} \mathrm{C}$ to avoid any change in mineralogy.

\subsection{Petrography study}

Thin sections were produced for a selection of representative samples to study petrography of the different lithological classes. Several studies were performed on all thin section to precise the separation of each sample in an alteration intensity class. This classification relies on macroscopic features (change of structure, color) and microscopic features (intensity of mineral replacement, type of neoformed minerals). It revealed that macroscopic observations were sufficient to classify each sample in an altered class. Primary minerals from fresh samples were determined under polarization microscope. According to Bernard (1999), Clauser and Huenges, (1995), Mielke et al., (2017), mineral composition has a significant impact on petrophysical properties. Unfortunately, no phase counting was done on minerals and linked with petrophysical properties because only phenocrysts can be counted. Microliths from the groundmass are too small to be determined accurately. Minerals and phases formed during alteration processes are small (cf. Figs. 5c and f) and characterized by standard X-ray techniques, on a powder with a particle size of $70-80 \mu \mathrm{m}$. XRD was performed using a Philips X'Pert PRO X-ray diffraction system (CEMEF Mines ParisTech Sophia-Antipolis), with Cu K-alpha radiation. Major element compositions of minerals were determined in thin sections by EPMA on a CAMECA SX-100 instrument equipped with five wavelength-dispersive X-ray spectrometers (WDS) at Service Microsonde Sud (Université de Montpellier). The analyses were done with $20 \mathrm{kV}$ accelerating voltage, a focused beam of $10 \mathrm{nA}$ and counting times of 20-30 s. Clay minerals like kaolinite, illite and smectite were identified with X-ray diffraction. Finally, magnetic minerals were investigated through reflected light and magnetic susceptibility variation with temperature (detailed in section 3.2.2). The objective of the magnetic mineral determination is to understand if the negative anomaly of magnetic susceptibility observed by Gailler et al. (2014) in the Bouillante geothermal province could be linked to variation in mineral content of the hydrothermally altered samples. 


\subsubsection{Chemical analyses}

Geochemical analyses were led only on lava flows to compare our results to previous studies and identify the chemical diversity of lava flows (Ricci et al., 2015a, 2015b, 2017; Samper et al., 2007; Zami et al., 2014). Whole-rock major and trace element analyses were performed at the Service d'Analyze des Roches et des Minéraux (SARM, CNRS, Nancy, France) on lava flows. Major elements contents were determined by ICPAES (Thermo Fischer ICap 6500) and trace element concentrations by ICP-MS (Thermo Elemental X7). Only major elements and especially total alkali and silica are exploited in this article.

\subsubsection{Magnetic susceptibility}

Three parameters were measured: the magnetic susceptibility; the magnetic fabric and the determination of magnetic minerals. The first one consists of measuring the total magnetic susceptibility directly on outcrops (Morgan et al., 2017) or on parallelepiped samples in laboratory with a GF Instruments model SM-20 handheld magnetic susceptibility meter. The SM-20 has a sensitivity of $10^{-6} \mathrm{SI}$ (International system of units) in the range $0-999.10^{-6} \mathrm{SI}$. This sensitivity is well below the values observed in the studied areas. The second one consists in measuring the anisotropy of magnetic susceptibility (AMS) on oriented cores $(2.1 \mathrm{~cm}$ height and

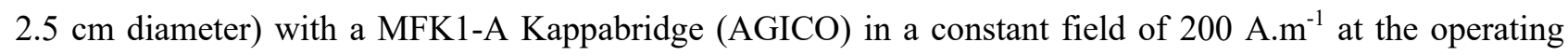
frequency $976 \mathrm{~Hz}$, using the 3-D rotator (Hrouda et al., 2015). AMS is a reliable method to access the bulk magnetic susceptibility and the magnetic fabric computing anisotropy degree of rocks (Jelinek, 1981). Finally the last parameter is measured using the evolution of magnetic susceptibility with temperature. Magnetic susceptibility evolution with temperature is an efficient method to identify magnetic minerals carrying the AMS (Panaiotu et al., 2011). The apparatus is approximately the same as AMS with MFK1-A Kappabridge, constant magnetizing field and operating frequency. However the device is coupled with a CS-L Cryostat and CS-4 Furnace permitting to study bulk magnetic susceptibility for temperatures between $-194^{\circ} \mathrm{C}$ and $700{ }^{\circ} \mathrm{C}$. The magnetic susceptibility variation with temperature was measured on samples reduced into thin powder. Measurement is performed under argon in three temperature intervals between $-194{ }^{\circ} \mathrm{C}$ and $20{ }^{\circ} \mathrm{C}$ thanks to liquid nitrogen, between $20^{\circ} \mathrm{C}$ and $700{ }^{\circ} \mathrm{C}$ (heating curve), and finally between $700^{\circ} \mathrm{C}$ and $20{ }^{\circ} \mathrm{C}$ (cooling curve). The determination of magnetic transitions during heating/cooling cycles like Curie temperature, Vervey transition for magnetite and Morin transition for hematite are indicators to identify magnetic minerals (Butler, 1998; Chadima, 2011). In this study, susceptibility vs. temperature curves are measured on lava flows with different alteration degree to identify the impact of hydrothermal alteration on magnetic minerals. 


\subsection{Thermal and physical measurements}

\subsubsection{Porosity and density}

Quantifying porosity is fundamental to estimate the volume available for fluid flow and storage. Only connected porosity was quantified. Three complementary methods using different saturation fluids have been selected to handle every sample.

The triple weighing method is defined by the norm RILEM (try ${ }^{\circ} \mathrm{I} .1,1978$ ). It is a reliable low-cost method, which permits to handle 50 samples with volumes between 10 and $50 \mathrm{~cm}^{3}$ each time and is nondestructive for cohesive samples without advancing argilaceous alteration. After a $48 \mathrm{~h}$ immersion the saturated mass and hydrostatic mass were measured to calculate effective porosity, sample volume and bulk density. As some volcanic materials are insufficiently cohesive or contain clays, saturation with water causes their destruction. Thus, fragile samples were not processed with this method.

Grain density depends on mineralogy and unconnected porosity since samples were not reduced into thin powder, which could remove every isolated pore. It was measured using a Micromeritics ${ }^{\circledR}$ model AccuPyc II 1340 gas pycnometer which allows to handle sample volumes between 10 and $50 \mathrm{~cm}^{3}$ (Aretz et al., 2015). It also allows a calculation of effective porosity using bulk density from triple weighing.

Measurements of connected porosity using water or helium are easy to perform and non-destructive methods, but they do not give any information about pore throat diameter. Mercury porosimetry was performed to access this parameter and avoid any former problem met with argilaceous rocks (Sizun, 1995; Washburn, 1921). Measurements have been performed with a Micromeritics ${ }^{\circledR}$ model AutoPore IV 9500 v1.09. This model investigates pore throat diameters from $360 \mu \mathrm{m}$ to $5.7 \mathrm{~nm}$. Moreover, it provides a lot of information like the pore size distribution, the total pore volume, the grain and bulk density (Belghoul, 2007; Giesche, 2006). Bulk density of low cohesive samples was determined using this method.

\subsubsection{Matrix permeability}

Intrinsic permeability $K$ measurements were performed thanks to a nitrogen permeameter under low confining pressure $(20$ bars $)$. It covers a wide range of permeability $\left(10^{-11} \mathrm{~m}^{2}\right.$ to $\left.10^{-19} \mathrm{~m}^{2}\right)$. The Klinkenberg effect was not taken into account to remove the slip flow phenomenon between gas molecules and solid walls (Klinkenberg, 1941). Indeed, measurements of permeability did not exhibit such effect. Measurements of permeability were performed on $25 \mathrm{~mm}$ diameter plugs for sufficiently cohesive lithotypes. For others, parallelepipeds were cut and included in fast setting epoxy resin to form $40 \mathrm{~mm}$ diameter plugs. Some 
pyroclastics like ashes and highly hydrothermalized rocks were not measured because they were not cohesive enough.

The number of measurement by sample is variable because some lavas where measured both parallel and perpendicular to lava flow. In most cases, only one plug was measured by sample because the measurement time was approximately two hours. The size of plugs and the number of measurement by sample is limited by the permeameter design that allows accurate measurements but cannot be repeated to several plugs by sample for our large set. Therefore, plugs were chosen to be the best representative of the sample.

\subsubsection{Thermal conductivity}

Thermal conductivity $\lambda$ and diffusivity $D$ were measured using a Thermal Conductivity Scanner from Lippmann \& Rauen GbR. The technique is based on the change in surface temperature after a known and set heat input and could be applied to a large range of geological materials (Boulanouar et al., 2013; Rosener, 2007; Stanek, 2013; Surma and Geraud, 2003). The measuring instrument includes a mobile plate composed of three thermal sensors and a heat source. The device has an accuracy of $3 \%$ in the measuring range from 0.2 to $25 \mathrm{~W} \cdot \mathrm{m}^{-1} \cdot \mathrm{K}^{-1}$. The procedure is described in detail by Popov et al. $(2016,1999)$. Temperature measurement occurs every $1 \mathrm{~mm}$ step.

For thermal diffusivity, the two standards have different thermal conductivity and diffusivity and temperature after heating is additionally measured with a third temperature sensor. Temperature measurement occurs every $2 \mathrm{~mm}$ step. The combination of bulk density, thermal conductivity and diffusivity allows the calculation of specific heat capacity $c_{p}$.

$\lambda$ and $D$ were measured in the three directions of blocks and then averaged to take account of possible anisotropy of rocks linked with specific mineral orientation, porosity and structure of the pore space.

\subsubsection{P-wave velocity}

The measurement of compressional waves velocity (P-waves) on dry samples was performed using ultrasonic velocity method with the Proceeq ${ }^{\circledR}$ brand PunditLab model (Bertrand, 2017; Bossennec et al., 2018; Haffen, 2012). It is a non-destructive testing based on the transmission of a pulse. The instrument is composed of two $54 \mathrm{kHz}$ piezoelectric transducers $\mathrm{P}$ (a transmitter and a receiver) and a pulse generator. The acoustic emission that arrives to the receiver is converted in an electrical signal acquired with a computer-controlled oscilloscope. The operating frequency was set constant at $54 \mathrm{kHz}$ and a shear gel was applied to facilitate a 
better connection. Compressional wave velocity was measured in the three directions of blocks and then averaged. Shear waves were not studied because of the difficulty to pick the first arrival of the S-wave in low cohesive samples.

\section{Results}

\subsection{Petrology and geochemistry}

A large amount of geochemical data is available both on Terre-de-Haut and Basse-Terre (e.g. Gadalia, 2013; Jacques et al., 1984; Jacques and Maury, 1988b; Samper et al., 2007, 2009). Samples of this study are complementary in location to those of the previous works since Samper et al. $(2009,2007)$ concentrated mostly on volcanic edifices and not on the coast.

Major elements were measured on 33 samples including 22 fresh lava flows and 11 slightly altered lava flows. Although $\mathrm{SiO}_{2}$ content varies between 55 and $65 \%$, most samples are andesites and basaltic andesites from the Axial Chain, and only few dacites from Terre-de-Haut and the Basal Complex (Fig. 3a). According to Peccerillo and Taylor (1976), most samples belong to calk-alcaline serie with 8 samples located between Beaugendre and Grande Rivière de Vieux-Habitants valleys belong to low differentiated lavas (in the tholeitic domain). Basse-Terre and Terre-de-Haut lavas belong to the Medium and Low K types $\left(\mathrm{K}_{2} 0: 0.55-1.56\right.$ wt.\%, Fig. 3b). Our geochemical data are consistent with previous studies which confirm the representativeness of the studied set of samples.
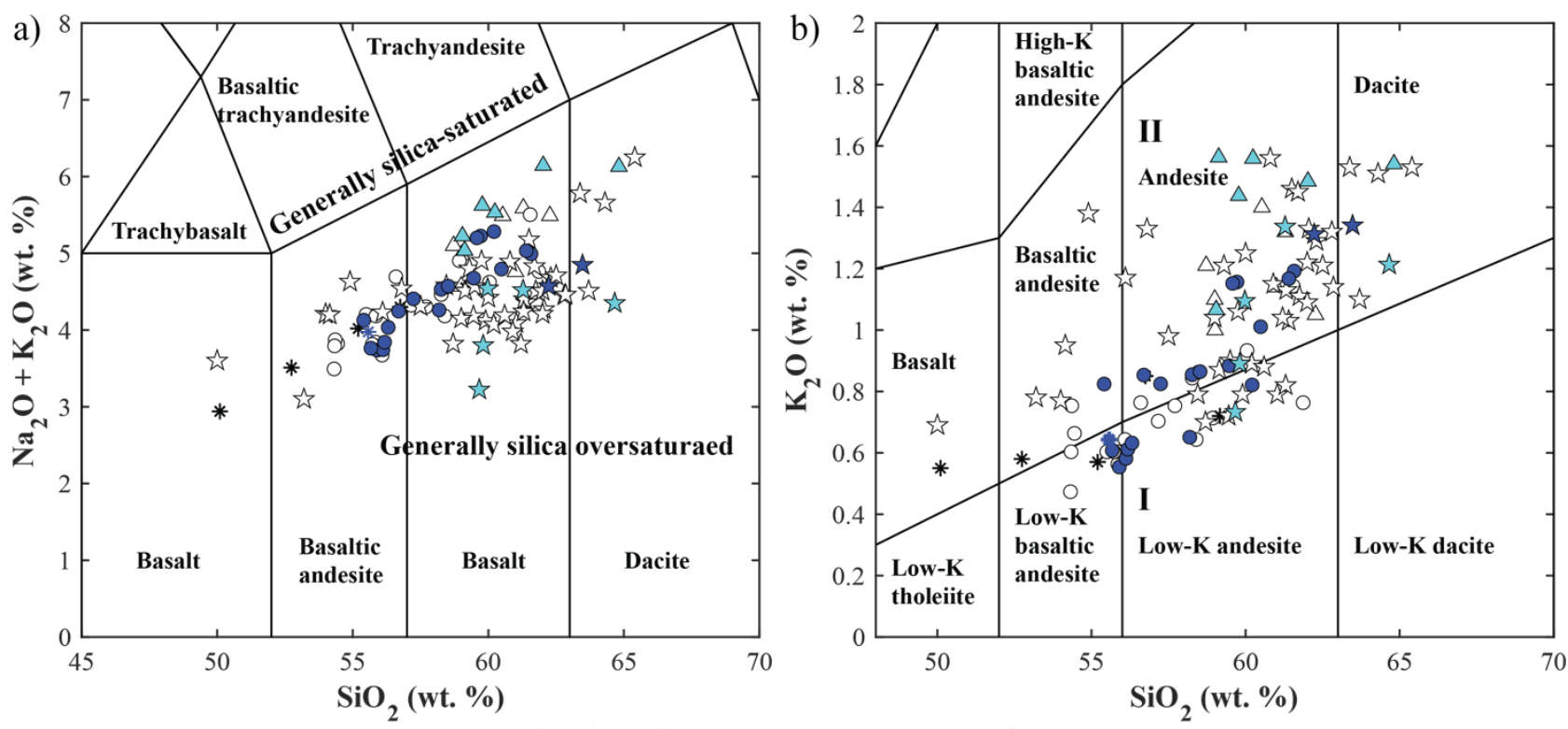

Published data: $\triangle$ Basal Complex $\bigcirc$ Piton de Bouillante $*$ Icaques is Terre-de-Haut

This study: $\bigcirc$ Piton de Bouillante - Fresh $*$ Icaques - Fresh $\star$ Terre-de-Haut - Fresh $\triangle$ Basal Complex - Slightly altered

is Terre-de-Haut - Slightly altered 


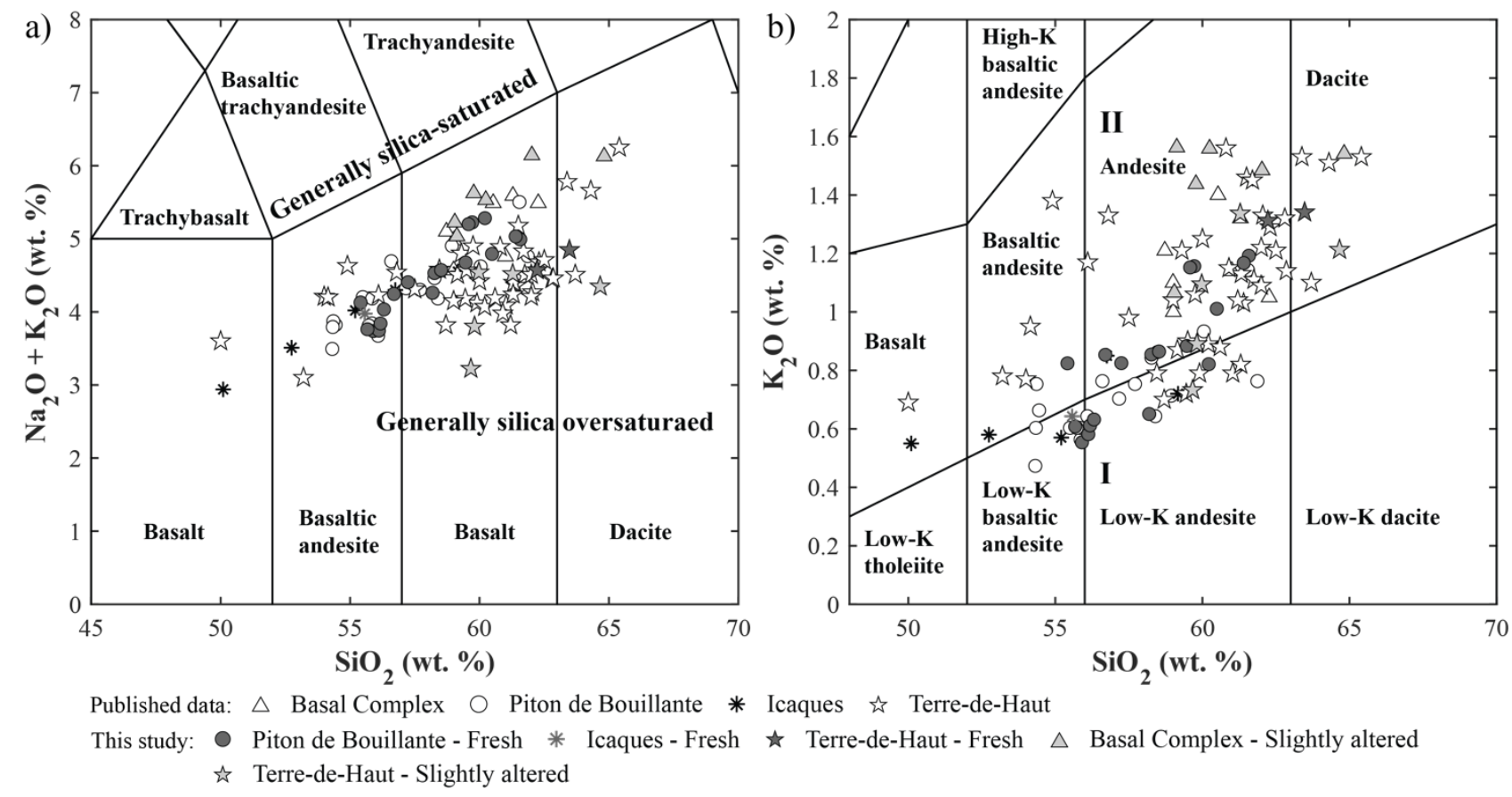

Fig. 3. Geochemical characterization of lava flows. a) total alkali vs. silica diagram after Bas et al. (1986); b) $\mathrm{SiO}_{2}$ vs. $\mathrm{K}_{2} \mathrm{O}$ plot after Peccerillo and Taylor (1976). I - calc-alkaline series; II - high-K calc-alkaline-series. Published geochemical data: Basal Complex Piton de Bouillante and Icaques (Ricci et al., 2017) ; Terre-de-Haut (Jacques et al., 1984; Zami et al., 2014). (COLOR FOR ONLINE VERSION ONLY / IMAGE SIZE: FULL PAGE WIDTH)

\subsubsection{Macroscopic and thin section observations}

All fresh lavas have porphyric textures and color from light to dark grey (Fig. 4). No specific mineral orientation was observed. Using thin section counting thanks to JMicroVision software (Roduit, 2007), phenocrysts represent $31 \%$ (20.7\% to $43.2 \%$ on 7600 points on 30 thin sections) of fresh lavas and are mostly composed of plagioclase $(\approx 80 \%)$ and in a lesser extent clinopyroxene and orthopyroxene $(\approx 15 \%)$ and iron oxides (magnetite and hematite, $\approx 5 \%$ ). This composition is in agreement with paragenesis found in previous studies (Boudon et al., 2008; Samper et al., 2007). Matrix is always composed of microlites of the same minerals and no glass was observed (Fig. 5a). Porosity is composed of different shape vesicles and microcracks crossing matrix and phenocrysts. Structure and texture of fresh lavas is preserved in slightly to moderately altered lavas. These lavas have various colors: greenish, white, medium grey and red (Fig. 4). They are composed of an averaged $20 \%$ of phenocrysts ( $4.4 \%$ to $36 \%$ on 4000 points on 16 thin sections). Alteration began to dissolve pyroxene minerals borders and central part but does not affect plagioclases. Chlorite, actinolite and pyrite appeared during this alteration phase (Fig. 5b). Neoformed minerals represent $30 \%$ of minerals present in phenocrysts. Porosity is composed by pores formed during dissolution in pyroxenes, initial cooling joints, small pores in matrix, microcracks crossing both phenocrysts and matrix and very rare vesicles. 
Hydrothermally altered lavas exhibit homogeneous light grey to white colors (Fig. 4). Hydrothermal alteration changed significantly the macroscopic aspect of lava. It produced a total replacement of microlites, pyroxenes and plagioclases phenocrysts by quartz, white micas, pyrite and calcite (Fig. 5c), reducing phenocrysts content to only $6 \%$ (2000 points on 8 thin sections).

Fresh debris flows and pyroclastics consist of same minerals as fresh lavas, but colors of rocks are much more heterogeneous because debris flows are composed of conglomerates of clasts (lavas, pyroclasts) and finegrained matrix. Porosity of debris flow is highly different from lavas. Indeed, the genesis of coarse deposits does not produce cooling structures or vesicles. However, arrangement of particles creates pores with sizes dependent of the size of particles (Fig. 5d). This porosity is added to the inherited porosity of cobbles and boulders composing debris flows. Slightly to moderately altered debris flows mostly sampled in the Basal Complex have greenish to purplish colors (Fig. 4). These debris flows are composed of the same minerals observed in slightly to moderately altered lavas. There is a clear decrease of inter-particular porosity compensated by partial dissolution of phenocrysts (Fig. 5e). Highly hydrothermalized debris flows are sampled majorly from Terre-de-Haut. Overall, such debris flows have white to yellow colors and contain a large amount illite, chlorite, smectite in matrix and gypsum, pyrite and calcite in fractures and bedding planes (Fig. 5f). Patchy alteration is common due to higher porosity of pyroclasts cobbles compared to debris flow matrix. These rocks are composed of 5\% of plagioclases (80-90\% transformed) and $95 \%$ of neoformed minerals. The well-known hydrothermal breccia from Bouillante bay that permitted the first Ar-Ar datation of the Bouillante field (Patrier et al., 2013; Verati et al., 2013) was classified in this lithotype. It is an entirely re-crystallized and silicified multicolored rock (Fig. 4, first row, line 6). Pores are essentially composed by cracks and dissolution voids resulting in disappearance of initial phenocrysts and particles. Pyroclastics and debris flows are mainly composed of plagioclases and pyroxenes and minor amphibole content. Ash deposits have wellmarked bedding caused by the homogeneous size of deposits. Pyroclastics are often poorly cohesive because there is no matrix linking elements together (Fig. 4). Cohesion depends on the degree of welding. Porosity is mainly due to voids between particles but intraparticular porosity may be high in ash and pumice particles. 


\begin{tabular}{|c|c|c|c|}
\hline Classification & Location & $\begin{array}{l}\text { Minerals / } \\
\text { Porosity }\end{array}$ & Samples \\
\hline Fresh lavas & $\begin{array}{l}\text { Axial Chain } \\
\text { Bouillante Chain } \\
\text { Terre-de-Haut }\end{array}$ & $\begin{array}{l}\text { Plagioclases ++++ } \\
\text { Pyroxenes ++ } \\
\text { Iron oxides + } \\
\text { Initial vesicles } \\
\text { Cooling joints } \\
\text { Micro-cracks } \\
\text { Fractures }\end{array}$ & \\
\hline $\begin{array}{l}\text { Slightly to } \\
\text { moderatelely } \\
\text { altered lavas }\end{array}$ & $\begin{array}{l}\text { Basal Complex } \\
\text { Bouillante Chain } \\
\text { Terre-de-Haut }\end{array}$ & $\begin{array}{l}\text { Plagioclases ++++ } \\
\text { Pyroxenes }+ \\
\text { Iron oxides }+ \\
\text { Chlorite, Micas }+ \\
\text { Dissolution } \\
\text { Cooling joints } \\
\text { Cracks } \\
\text { Fractures } \\
\end{array}$ & \\
\hline $\begin{array}{l}\text { Highly } \\
\text { hydrothermalized } \\
\text { lavas }\end{array}$ & $\begin{array}{l}\text { Northern Chain } \\
\text { Terre-de-Haut }\end{array}$ & $\begin{array}{l}\text { Plagioclases ++ } \\
\text { Calcite, Pyrite ++ } \\
\text { Clay Minerals ++ } \\
\text { Micas, Chlorite + } \\
\text { Dissolution } \\
\text { Cooling joints } \\
\text { Cracks } \\
\text { Fractures }\end{array}$ & \\
\hline Fresh debris flows & $\begin{array}{l}\text { Axial Chain } \\
\text { Bouillante Chain } \\
\text { Terre-de-Haut }\end{array}$ & $\begin{array}{l}\text { Plagioclases }++++ \\
\text { Pyroxenes }++ \\
\text { Iron oxides }+ \\
\text { Plant residues }+ \\
\text { Interparticular } \\
\text { Intraparticular } \\
\text { Micro-cracks } \\
\text { Fractures } \\
\end{array}$ & \\
\hline $\begin{array}{l}\text { Slightly to } \\
\text { moderately altered } \\
\text { debris flows }\end{array}$ & $\begin{array}{l}\text { Basal Complex } \\
\text { Terre-de-Haut }\end{array}$ & $\begin{array}{l}\text { Plagioclases }+++ \\
\text { Pyroxenes }+ \\
\text { Iron oxides }+ \\
\text { Chlorite, Quartz }+ \\
\text { Pyrophyllite } \\
\text { Dissolution } \\
\text { Cracks } \\
\text { Fractures }\end{array}$ & \\
\hline $\begin{array}{l}\text { Highly } \\
\text { hydrothermalized } \\
\text { debris flows }\end{array}$ & $\begin{array}{l}\text { Axial Chain } \\
\text { Bouillante Chain } \\
\text { Terre-de-Haut }\end{array}$ & $\begin{array}{l}\text { Plagioclases ++ } \\
\text { Pyroxenes + } \\
\text { Qz, Gp, Calcite ++ } \\
\text { Chlorite, Epidote + } \\
\text { White micas + } \\
\text { Dissolution } \\
\text { Cracks } \\
\text { Fractures } \\
\end{array}$ & \\
\hline Fresh pyroclastics & $\begin{array}{l}\text { Bouillante Chain } \\
\text { Grande-Decouverte } \\
\text { volcano }\end{array}$ & $\begin{array}{l}\text { Plagioclases ++++ } \\
\text { Pyroxenes ++ } \\
\text { Iron oxides + } \\
\text { Interparticular } \\
\text { Intraparticular } \\
\text { Cracks } \\
\text { Vesicles }\end{array}$ & \\
\hline
\end{tabular}




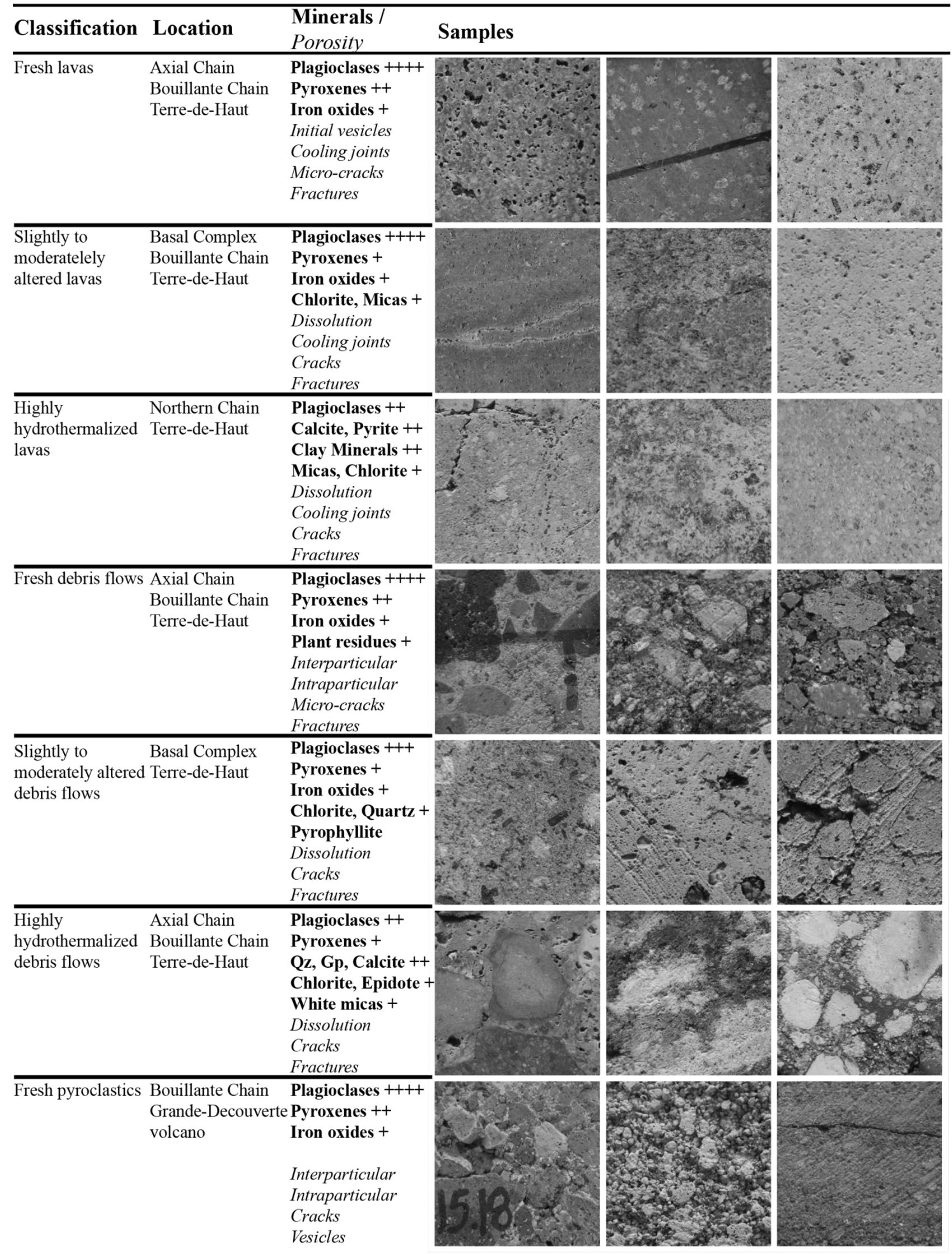


Fig. 4. Short description of the seven lithological classes with macroscopic pictures of the different rocks in each lithological class. Each picture is $3.5 \mathrm{~cm}$ size. Qz - quartz; Gp - Gypsum (COLOR FOR ONLINE VERSION ONLY / IMAGE SIZE: FULL PAGE)
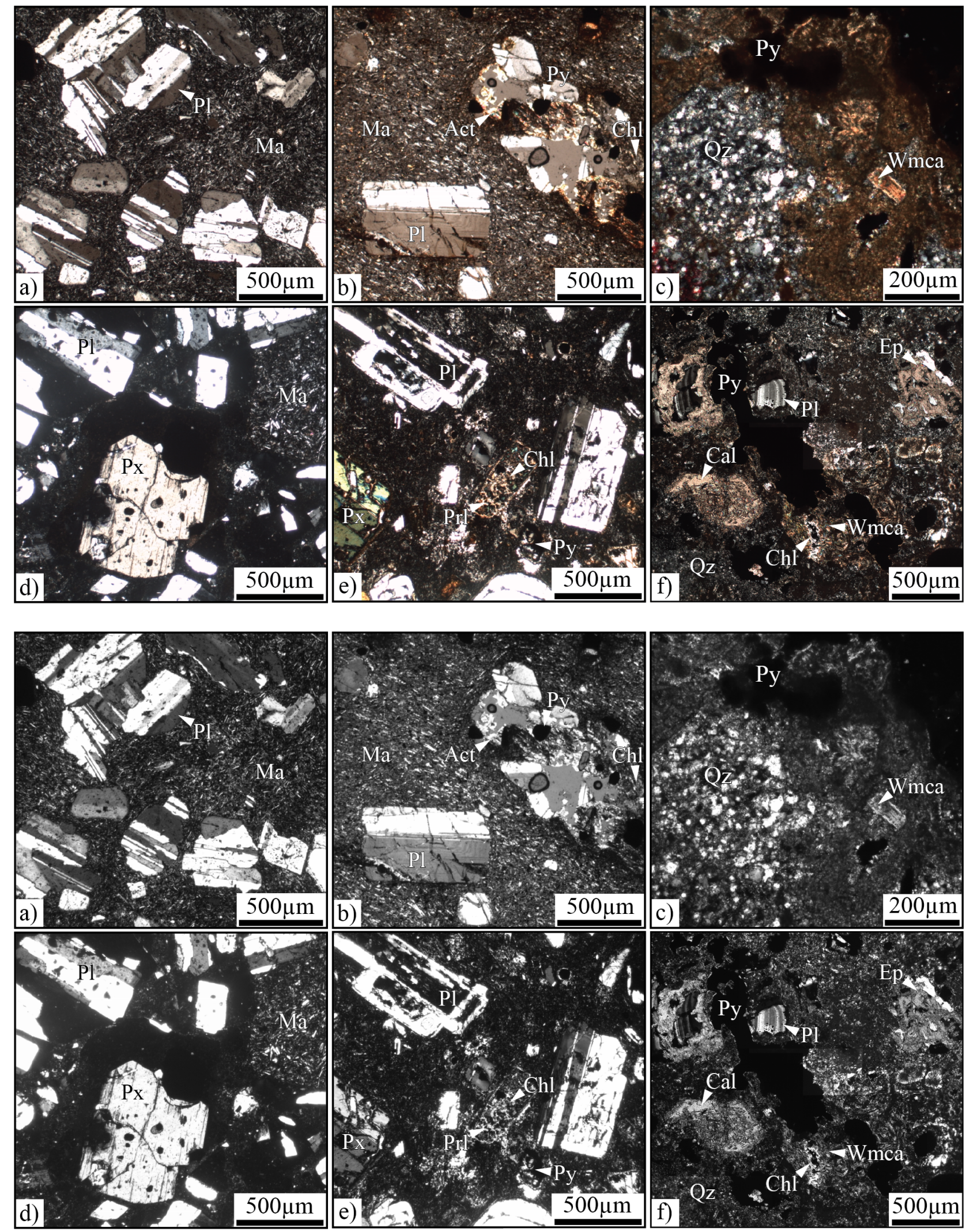

Fig. 5. Thin section photomicrographs of lava flows and debris flows (cross polarized light ). Lava flows are on the top line: a) fresh lava flow from Les Trois Tortues; b) moderately hydrothermalized lava flow from 
Anse Tillet; c) highly hydrothermalized lava flow in La Savane. Coarse volcano sedimentary deposits are represented in the line below with: d) coarse debris flow from the Val de l'Orge bay; e) moderately hydrothermalized debris flow from the Amandiers beach and f) highly hydrothermalized debris flow from Grande Anse Bay. Abbreviations: Act - actinolite, Cal - calcite, Chl - chlorite, Ep - epidote, Ma - microlithic matrix, Pl - plagioclase, Prl - pyrophyllite, Px - pyroxene, Py - pyrite, Qz - quartz, Wmca - white mica.

\section{(COLOR FOR ONLINE VERSION ONLY / IMAGE SIZE: FULL PAGE)}

\subsubsection{Magnetic susceptibility data}

Measurement of magnetic susceptibility was performed using three methods. The quickest and easiest one consisted in measuring susceptibility directly on outcrops or on rock blocks with sufficiently flat surfaces. It permitted to obtain susceptibility values for every sample on contrary to AMS method, which needs samples strong enough to be plugged. Median values of total magnetic susceptibility are $11.6 .10^{-3}$ and $7.5 \cdot 10^{-3} \mathrm{SI}$ respectively for fresh lavas and debris flows which is slightly higher than pyroclastics $6.6 .10^{-3} \mathrm{SI}$ (Table 1). This intensity of magnetic signal cannot be only explained by the presence of paramagnetic pyroxenes and it indicates relatively high amounts of magnetic minerals (Hrouda et al., 2015). Total magnetic susceptibility of slightly to moderately altered lavas and debris flows has higher median values than fresh samples $\left(12.10^{-3}\right.$ and 17.2.10 $0^{-3}$ SI respectively). The first phase of alteration that transforms initial minerals (pyroxenes and plagioclases) and concentrates iron oxides content leads to a slight increase of magnetic susceptibility. Finally, samples affected by advancing hydrothermal alteration have the same median value $0.1 .10^{-3} \mathrm{SI}$. The total transformation of initial minerals by hydrothermal alteration removes magnetic minerals too. These results are concordant with those acquired by Gailler et al. (2014). Trends are similar for lavas and debris flows. Results obtained with AMS are approximately the same for lavas but display a lower signal in debris flows. This may be due to the reduced number of samples. But the general behavior with advancing alteration remains the same. The slight increase of magnetic susceptibility with moderate alteration and the reduction of magnetization with advancing hydrothermal alteration are obvious too. High temperature hydrothermal alteration removes magnetic minerals. AMS highlights that magnetic fabrics of lavas are weakly anisotropic (corrected degree of anisotropy between 1.002 and 1.054). This anisotropy is logically oriented in the direction of flow in lavas determined on the field thanks to closely spaced parallel cooling joints, which are parallel to the lava flow margins (Mathieu, 2010). This preferential mineral orientation in lavas was not observed during thin section observations. 
Table 1 Summary of magnetic susceptibility measurements on outcrops and blocks with handheld susceptibility meter and using AMS. (TABLE SIZE: FULL PAGE)

\begin{tabular}{|c|c|c|c|c|c|c|c|c|}
\hline & \multirow[b]{2}{*}{$\begin{array}{l}\text { Total } \\
\text { susceptibility } \\
{\left[\begin{array}{lll}\mathrm{x} & \left.10^{-3} \mathrm{SI}\right]\end{array}\right.}\end{array}$} & \multicolumn{3}{|c|}{ Lava flow } & \multicolumn{3}{|c|}{ Debris flow } & \multirow{2}{*}{\begin{tabular}{|l|} 
Pyroclastics \\
Fresh
\end{tabular}} \\
\hline & & Fresh & $\begin{array}{l}\text { Slightly to } \\
\text { moderately } \\
\text { altered }\end{array}$ & Highly altered & Fresh & $\begin{array}{l}\text { Slightly to } \\
\text { moderately } \\
\text { altered }\end{array}$ & Highly altered & \\
\hline \multirow{4}{*}{$\begin{array}{c}\text { Field } \\
\text { susceptibility } \\
\text { meter }\end{array}$} & Average & 13.92 & 13.34 & 5.99 & 9.36 & 13.19 & 0.94 & 8.84 \\
\hline & Median & 11.60 & 11.97 & 0.09 & 7.54 & 17.17 & 0.14 & 6.60 \\
\hline & Min - Max & $2.06-26.8$ & $3.58-27.62$ & $-0.04-21.47$ & $3.89-24.9$ & $3.96-18.37$ & $-0.17-5.04$ & $4.88-19.33$ \\
\hline & $\mathrm{n}$ & 41 & 23 & 7 & 20 & 7 & 7 & 14 \\
\hline \multirow{4}{*}{ AMS } & Average & 15.68 & 12.86 & 0.02 & 5.84 & 5.38 & 1.57 & 15.55 \\
\hline & Median & 12.05 & 13.36 & 0.02 & 4.65 & 5.38 & 0.29 & 15.59 \\
\hline & Min - Max & $3.54-32.7$ & $0.57-20.91$ & $0.02-0.02$ & $4.19-9.34$ & $5.37-5.4$ & $0.24-4.17$ & $11.15-21.13$ \\
\hline & $\mathrm{n}$ & 157 & 28 & 1 & 5 & 2 & 3 & 9 \\
\hline
\end{tabular}

Thermomagnetic curves obtained on a selected set of lavas with different degree of alteration (Fig. 6) provide information on the nature of minerals holding the magnetic signal. The most striking feature is the difference between heating and cooling curves. For fresh and slightly to moderately altered samples, the heating curve run much higher than the cooling curve. The opposite relationship exists for highly hydrothermalized samples from the central part of Terre-de-Haut Island. This large difference between heating and cooling curves indicates that the assemblage of magnetic minerals is unstable caused by possible postmagmatic alterations occurring during magma cooling (Hrouda et al., 2015). Fresh lava samples show a constant substantial decrease of mass susceptibility between 480 and $600^{\circ} \mathrm{C}$, which may indicate the presence of titanomagnetite and magnetite. The heating curve of the moderately altered sample exhibits two decreases of susceptibility. The first one is a medium decrease between 400 and $540{ }^{\circ} \mathrm{C}$ and the second one is a major drop between 540 and $600{ }^{\circ} \mathrm{C}$ certainly due to the presence of maghemite and titanomagnetite. A coupled analysis using reflected light microscopy and XRD confirmed these results. It highlights also a progressive transformation of magnetite into hematite along microcracks in moderately altered lavas. Highly hydrothermalized lavas have a mass susceptibility two order of magnitude lower than fresh lavas. The susceptibility between -194 and $700{ }^{\circ} \mathrm{C}$ is almost unchanged except one peak at $560^{\circ} \mathrm{C}$. Thin section analysis shows the absence of magnetite and hematite in these rocks, which explains the large decrease of the magnetic signal. Iron oxides are totally replaced by pyrite during hydrothermal alteration. 

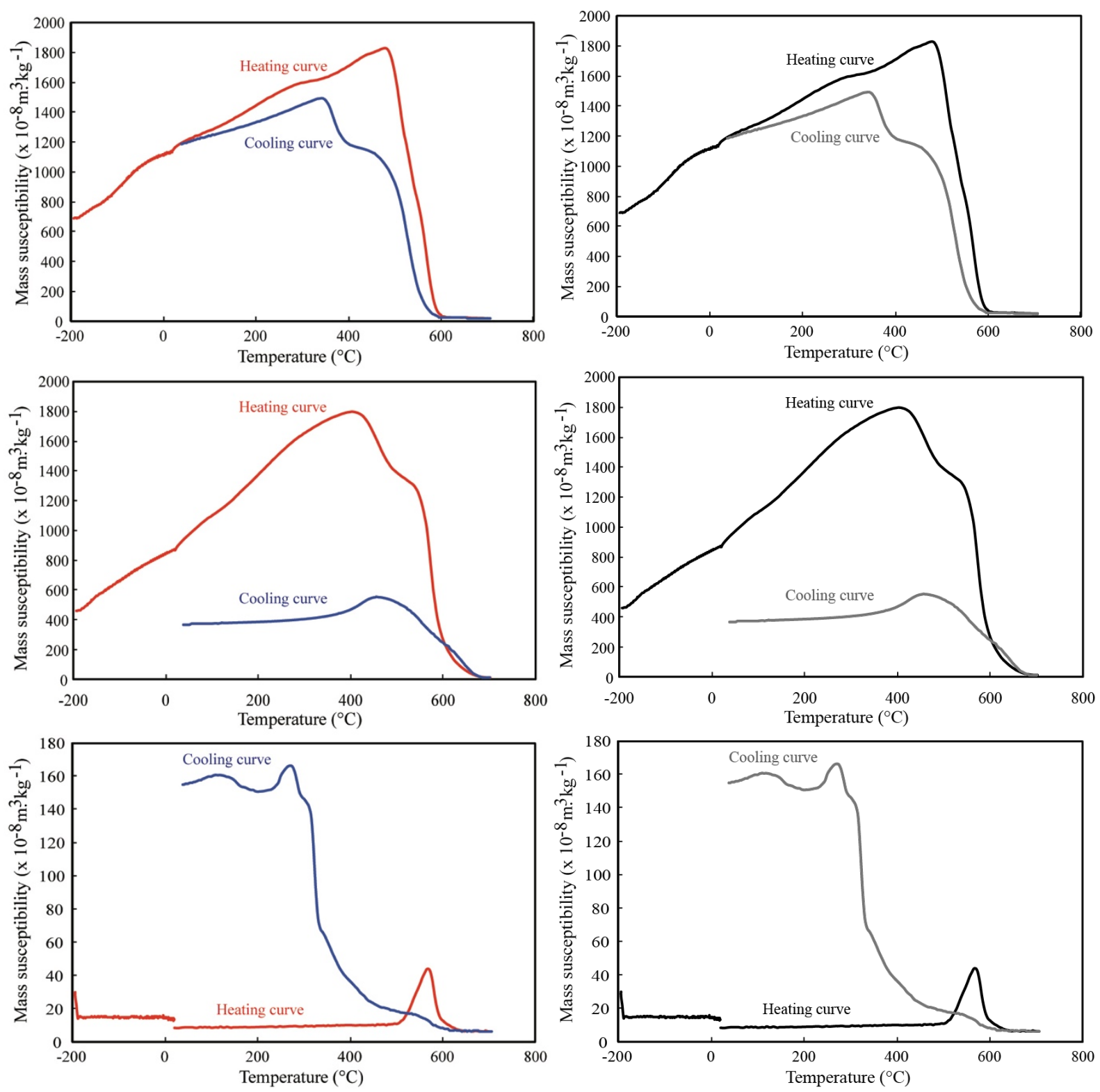

Fig. 6. Evolution of magnetic susceptibility with temperature for lavas in 3 alteration stages. From top to bottom, fresh andesite lava flow from Duché (Vieux-Habitants area), moderately hydrothermalized andesite lava flow from Pointe Riflet (Basal Complex) and highly hydrothermalized lava flow from Grande Anse Bay (Terre-de-Haut). (COLOR FOR ONLINE VERSION ONLY / IMAGE SIZE: SMALL COLUMN WIDTH) 
Table 2 summarizes median values and ranges for all measured properties

Table 2 Statistical overview of measured thermo-physical properties. $\rho_{\mathrm{b}}$ : bulk density, $\rho_{\mathrm{s}}$ : grain density, $\Phi_{\mathrm{Hg}}$ : mercury porosity, $\Phi_{\mathrm{w}}$ : water porosity, $\Phi_{\mathrm{He}}$ : helium porosity, $\mathrm{K}$ : permeability (measurement limits $10^{-19}-10^{-11} \mathrm{~m}^{2}$ ), $\mathrm{V}_{\mathrm{P}}$ : P-wave velocity, $\lambda$ : thermal conductivity, D: thermal diffusivity, $c_{p}$ : specific heat capacity. $n$ : number of measurements (IMAGE

\section{SIZE: FULL PAGE)}

\begin{tabular}{|c|c|c|c|c|c|c|c|c|c|c|c|c|}
\hline $\begin{array}{l}\text { Lithological } \\
\text { class }\end{array}$ & Alteration & & $\begin{array}{l}\rho \mathrm{b} \\
{\left[\mathrm{g} \cdot \mathrm{cm}^{-3}\right]}\end{array}$ & $\begin{array}{l}\rho \mathrm{s} \\
{\left[\mathrm{g} . \mathrm{cm}^{-3}\right]}\end{array}$ & $\begin{array}{l}\Phi \mathrm{Hg} \\
{[\%]}\end{array}$ & $\begin{array}{l}\Phi_{\mathrm{W}} \\
{[\%]}\end{array}$ & $\begin{array}{l}\Phi \mathrm{He} \\
{[\%]}\end{array}$ & $\begin{array}{l}\mathrm{K} \\
{\left[\mathrm{m}^{2}\right]}\end{array}$ & $\begin{array}{l}\mathrm{VP} \\
{\left[\mathrm{m} \cdot \mathrm{s}^{-1}\right]}\end{array}$ & $\begin{array}{l}\lambda \\
{\left[\mathrm{W} \cdot \mathrm{m}^{-1} \cdot \mathrm{K}^{-1}\right]}\end{array}$ & $\begin{array}{l}\mathrm{D} \\
{\left[\mathrm{x} \quad 10^{-6} \mathrm{~m}^{2} \cdot \mathrm{s}^{-}\right.} \\
\left.{ }^{1}\right]\end{array}$ & $\begin{array}{l}\mathrm{CP} \\
{\left[\mathrm{kJ} \cdot \mathrm{kg}^{-1} \cdot \mathrm{K}^{-1}\right]}\end{array}$ \\
\hline \multirow[t]{12}{*}{$\begin{array}{l}\text { Andesite } \\
\text { lava }\end{array}$} & \multirow{4}{*}{$\begin{array}{l}\text { Fresh } \\
28 \text { blocks }\end{array}$} & Median & 2.64 & 2.75 & 4.00 & 3.59 & 3.85 & $6 E-18$ & 4589 & 1.68 & 0.88 & 0.75 \\
\hline & & Average & 2.61 & 2.75 & 6.61 & 4.98 & 5.32 & $2 \mathrm{E}-14$ & 4627 & 1.62 & 0.84 & 0.76 \\
\hline & & Min - Max & $2.17-2.77$ & $2.61-2.85$ & $1.1-22.8$ & $0.03-19.7$ & $1.4-23.9$ & $\begin{array}{l}1 \mathrm{E}-19-8 \mathrm{E}- \\
13\end{array}$ & $2876-6233$ & $0.76-1.98$ & $0.5-0.97$ & $0.7-0.82$ \\
\hline & & $\mathrm{n}$ & 210 & 80 & 31 & 209 & 55 & 46 & 34 & 50 & 25 & 28 \\
\hline & \multirow{4}{*}{$\begin{array}{l}\begin{array}{l}\text { Slightly to } \\
\text { moderately } \\
\text { altered }\end{array} \\
16 \text { blocks }\end{array}$} & Median & 2.49 & 2.62 & 5.91 & 4.07 & 4.63 & $4 \mathrm{E}-15$ & 4490 & 1.65 & 0.75 & 0.89 \\
\hline & & Average & 2.42 & 2.61 & 11.03 & 7.89 & 10.72 & $8 \mathrm{E}-15$ & 3947 & 1.52 & 0.72 & 0.89 \\
\hline & & Min - Max & $1.6-2.64$ & $2.5-2.74$ & $1.4-27.6$ & $0.04-32.2$ & $1.2-35.9$ & $\begin{array}{l}1 \mathrm{E}-19-1 \mathrm{E}- \\
13\end{array}$ & $1412-5362$ & $0.78-1.88$ & $0.46-0.92$ & $0.78-1.06$ \\
\hline & & $\mathrm{n}$ & 33 & 26 & 15 & 32 & 19 & 17 & 16 & 25 & 14 & 16 \\
\hline & \multirow{4}{*}{$\begin{array}{l}\text { Highly } \\
\text { altered } \\
6 \text { blocks }\end{array}$} & Median & 2.00 & 2.73 & 20.44 & 22.88 & 25.84 & 2E-14 & 1837 & 1.66 & 0.92 & 0.97 \\
\hline & & Average & 2.05 & 2.71 & 19.16 & 22.63 & 25.99 & $1 \mathrm{E}-13$ & 1668 & 1.71 & 0.97 & 0.92 \\
\hline & & Min - Max & $1.97-2.25$ & $2.61-2.8$ & $14.2-21.5$ & $18.6-26.1$ & $24.7-27.6$ & $\begin{array}{l}1 \mathrm{E}-17-5 \mathrm{E}- \\
13\end{array}$ & $500-2660$ & $1.38-2.08$ & $0.66-1.4$ & $0.69-1.06$ \\
\hline & & $\mathrm{n}$ & 6 & 7 & 4 & 5 & 4 & 4 & 5 & 9 & 6 & 6 \\
\hline \multirow[t]{12}{*}{ Debris flow } & \multirow{4}{*}{$\begin{array}{l}\text { Fresh } \\
22 \text { blocks }\end{array}$} & Median & 1.63 & 2.60 & 32.56 & 34.18 & 37.52 & 4E-14 & 2059 & 0.67 & 0.47 & 0.88 \\
\hline & & Average & 1.74 & 2.58 & 32.67 & 32.34 & 35.67 & $5 \mathrm{E}-13$ & 2020 & 0.73 & 0.48 & 0.89 \\
\hline & & Min - Max & $1.33-2.29$ & $2.3-2.8$ & $15.4-46.5$ & $15.9-44.8$ & $15.9-45.6$ & $\begin{array}{l}1 \mathrm{E}-16-7 \mathrm{E}- \\
12\end{array}$ & $635-3330$ & $0.43-1.36$ & $0.28-0.86$ & $0.6-1.19$ \\
\hline & & $\mathrm{n}$ & 25 & 44 & 21 & 25 & 22 & 16 & 23 & 33 & 20 & 22 \\
\hline & \multirow{3}{*}{$\begin{array}{l}\text { Slightly to } \\
\text { moderately } \\
\text { altered }\end{array}$} & Median & 1.97 & 2.62 & 23.55 & 25.37 & 28.25 & 1E-15 & 2379 & 1.02 & 0.59 & 0.90 \\
\hline & & Average & 1.99 & 2.61 & 23.90 & 24.18 & 26.38 & $6 \mathrm{E}-15$ & 2200 & 1.07 & 0.62 & 0.87 \\
\hline & & Min - Max & $1.84-2.14$ & $2.52-2.67$ & $17.9-28.7$ & $19.1-29.1$ & 19.6 - 29.4 & $\begin{array}{l}2 \mathrm{E}-16-3 \mathrm{E}- \\
14\end{array}$ & $1370-2695$ & $0.92-1.3$ & $0.56-0.79$ & $0.72-0.93$ \\
\hline & 6 blocks & $\mathrm{n}$ & 7 & 10 & 6 & 6 & 5 & 5 & 9 & 12 & 6 & 6 \\
\hline & \multirow{4}{*}{ 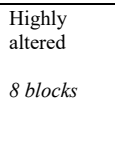 } & Median & 1.50 & 2.62 & 30.44 & 41.47 & 36.26 & $5 E-16$ & 1636 & 0.85 & 0.44 & 0.97 \\
\hline & & Average & 1.65 & 2.59 & 33.71 & 35.82 & 33.22 & $2 \mathrm{E}-13$ & 1683 & 0.97 & 0.59 & 1.00 \\
\hline & & Min - Max & $1.21-2.3$ & $2.36-2.7$ & $15.4-52.4$ & $11.9-50.6$ & $12-48.4$ & $\begin{array}{l}7 \mathrm{E}-18-5 \mathrm{E}- \\
13\end{array}$ & $790-3623$ & $0.5-1.81$ & $0.42-1.1$ & $0.72-1.62$ \\
\hline & & $\mathrm{n}$ & 7 & 9 & 7 & 5 & 4 & 3 & 8 & 11 & 8 & 8 \\
\hline \multirow[t]{4}{*}{ Pyroclastics } & \multirow{4}{*}{$\begin{array}{l}\text { Fresh } \\
15 \text { blocks }\end{array}$} & Median & 1.52 & 2.65 & 34.24 & 41.96 & 42.33 & $8 E-13$ & 1642 & 0.54 & 0.40 & 0.88 \\
\hline & & Average & 1.53 & 2.61 & 37.81 & 43.53 & 44.82 & $2 \mathrm{E}-12$ & 1767 & 0.56 & 0.41 & 0.86 \\
\hline & & Min - Max & $0.62-2.42$ & $2.21-2.79$ & $20.2-63$ & $21.6-74$ & $21.6-76.1$ & $\begin{array}{l}2 \mathrm{E}-14-1 \mathrm{E}- \\
11\end{array}$ & $500-3584$ & $0.26-1.11$ & $0.29-0.57$ & $0.63-1.12$ \\
\hline & & $\mathrm{n}$ & 20 & 30 & 16 & 17 & 16 & 10 & 17 & 25 & 14 & 15 \\
\hline
\end{tabular}

\subsubsection{Porosity and pore throat diameter}

The measurement of porosity using mercury as saturation fluid was performed on 99 samples. Figure 7 displays results for a selection of representative samples from the seven lithological classes. We decided to represent common mercury injection curves with bar charts to simplify the interpretation. An empiric lower limit of $40 \%$ of the maximal mercury intrusion was established to remove every pore throat diameter below this limit. The diameter corresponding to the maximal intrusion was defined as the percolation threshold (Fig. 7, diamond symbol). The narrowest bars are, the most homogeneous is the pore network. Fresh lava flows may be divided in two groups. The first one corresponds to low porosity samples without vesicles $(\Phi<5 \%)$, pore 
throat diameters below $0.5 \mu \mathrm{m}$ and percolation thresholds generally under $0.05 \mu \mathrm{m}$. Porosity is essentially composed of micro-cracks crossing matrix and phenocrysts. The second group gathers lavas where vesicles present different shapes and porosities higher than $5 \%$. Their pore network is more homogeneous and often limited to a small injection interval with percolation thresholds higher than $1 \mu \mathrm{m}$. Some samples with millimeter size vesicles have a small part of porosity that cannot be detected because pore throat diameters are above detection limit. Porosity is essentially composed by well-opened vuggy pores or tight elongated vesicles oriented in the direction of magma flow. Slightly to moderately altered lavas have a large range of porosity $(1.4-27.6 \%)$ with pore throat diameters under $0.01 \mu \mathrm{m}$. The pore network of samples from the Basal Complex with planar bedding (GD15.01 and GD15.42) has a very limited pore throat diameter range. Highly hydrothermalized lavas from Terre-de-Haut have porosities higher than $15 \%$ and there is no pore throat diameter larger than $5 \mu \mathrm{m}$. Weathering and hydrothermal alteration increase homogeneity of pore network reducing the variability of throat diameter in lavas.

Fresh debris flows and pyroclastics have high porosity values. Porosity ranges between $15 \%$ for coarse volcanic breccia to more than $60 \%$ for some pumice. Injection of mercury concerns a wider range of pore throat diameters than fresh lavas even if the major part of porosity has thresholds below $50 \mu \mathrm{m}$. Two individual pore networks may explain this heterogeneity: intra-clast pores with thresholds below $0.05 \mu \mathrm{m}$ and intergranular porosity with pore throats between 0.05 and $50 \mu \mathrm{m}$. For the majority of samples, percolation thresholds are close to $5 \mu \mathrm{m}$. Slightly to moderately altered and hydrothermalized debris flows have similar porosity values but the injection of mercury is more continuous below $5 \mu \mathrm{m}$. Moreover, percolation thresholds tend to decrease progressively with advancing hydrothermal alteration with values close to $0.05 \mu \mathrm{m}$ for the most transformed samples. 


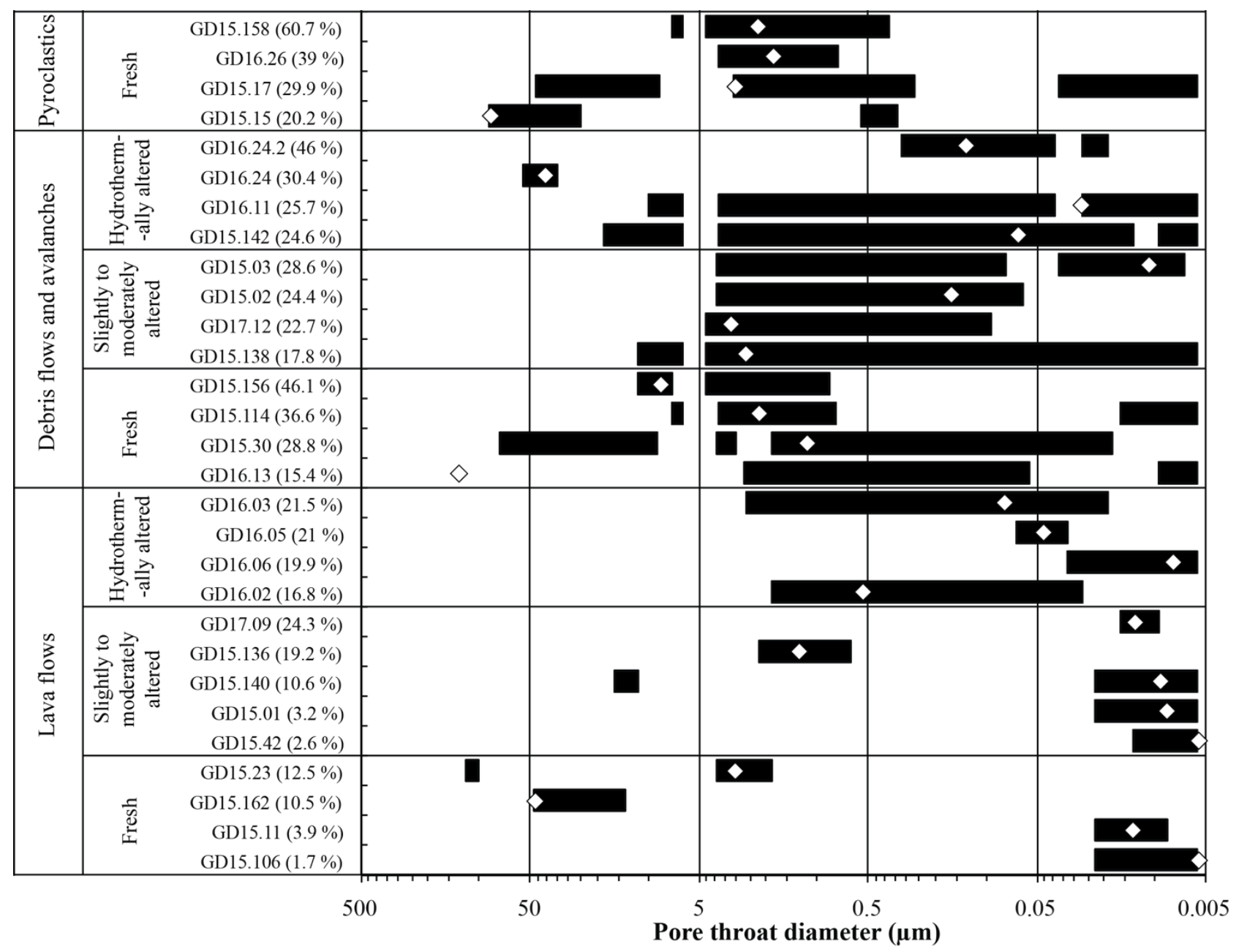

Fig. 7. Pore throat diameter of selected samples from the seven investigated lithotypes. Samples from every lithotypes are sorted in ascending porosity. Bars represent pore throat diameters corresponding at least to $40 \%$ of the maximal injection of mercury. Diamond symbols represent the percolation threshold where the peak injection of mercury occurs.

(IMAGE SIZE: ONE AND A HALF PAGE WIDTH)

\subsubsection{Density vs. porosity}

Bulk and grain densities were measured on all investigated lithotypes (Fig. 8a). There is no clear trend between the two properties. Maximal median values of grain density are observed for fresh and highly hydrothermalized lava flows (2.75 and $2.73 \mathrm{~g} . \mathrm{cm}^{-3}$ respectively). Slightly to moderately altered lavas, debris flows and pyroclastics have similar grain densities comprised between 2.6 and $2.65{\mathrm{~g} . \mathrm{cm}^{-3}}^{-3}$ Grain densities exhibit a significant dispersion between 2.21 and $2.85 \mathrm{~g} . \mathrm{cm}^{-3}$ with only three samples below $2.4 \mathrm{~g} . \mathrm{cm}^{-3}$. It can be explained as a larger amount of porosity inaccessible by helium but accessible with water because their bulk densities are not abnormally low compared to other debris flows and pyroclastic samples. Grain densities of fresh lavas range between 2.61 to $2.85 \mathrm{~g} . \mathrm{cm}^{-3}$. Such difference may be caused mostly by $\mathrm{SiO}_{2}$ content, which varies inversely to grain density and secondarily to unconnected porosity. The partial transformation of 
minerals in slightly to moderately altered lavas decreases the grain density in comparison with fresh lavas. CaAl-pyroxenes $\left(\rho_{s}=3.36\right.$ - Schön, 2015) are replaced by chlorite $\left(\rho_{s}=2.8\right.$ - Schön, 2015) and pyrophyllite $(\rho s=2.65-2.9, w w w . m i n d a t . o r g)$. The surprisingly high grain density of hydrothermalized lavas is due to the high pyrite content ( $\rho_{s}=5.011$ - Schön, 2015) compensating the lower density of the porous clay minerals. The major part of debris flows and pyroclastics have similar grain densities to lavas between 2.55 and 2.8 $\mathrm{g} . \mathrm{cm}^{-3}$. This result seems logical for fresh debris flows since they are formed from the dismantling of unstable volcanic edifice slopes composed by pyroclastics and lavas. On the contrary to lavas, the hydrothermally altered debris flows do not contain pyrite. They have a large amount of low density gypsum $\rho_{s}=2.305$ (Schön, 2015), compensated by calcite, 2.71 (Schön, 2015), and quartz, 2.648 (Schön, 2015) which give grain densities similar to fresh debris flows.

Bulk densities range remarkably from 0.62 to $2.77 \mathrm{~g} . \mathrm{cm}^{-3}$ for pumice and fresh lava respectively. It mirrors mercury porosity values (Fig. 8b). Overall, the majority of lavas follow the general trend on contrary to the slight dispersion of debris flows and pyroclastics. 

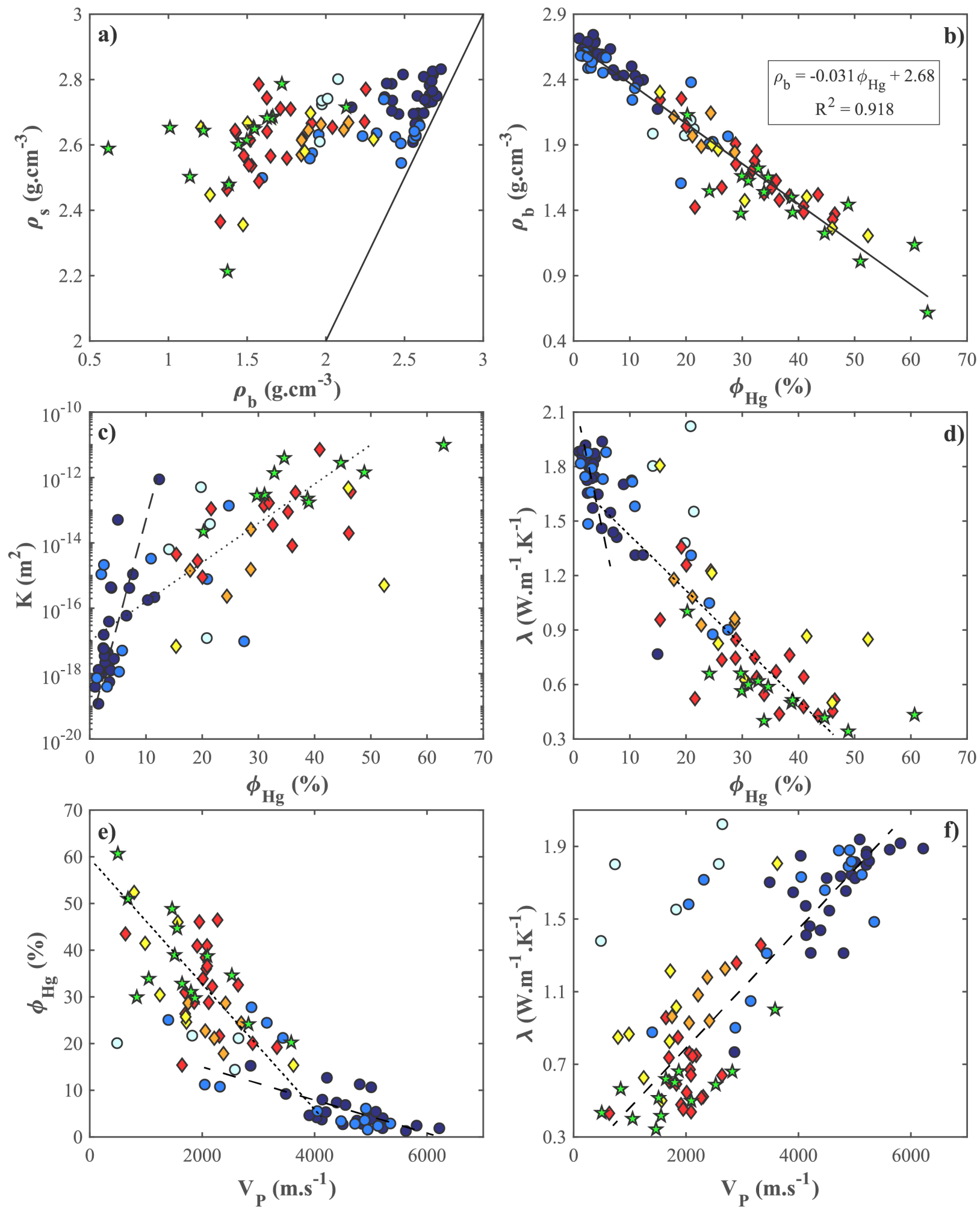

- Fresh lavas o Slig. to mod. altered lavas $\bigcirc$ Hydrothermalized lavas $\quad$ Fresh pyroclastics

$\diamond$ Fresh debris flows $\diamond$ Slig. to mod. altered debris flows $\diamond$ Hydrothermalized debris flows 

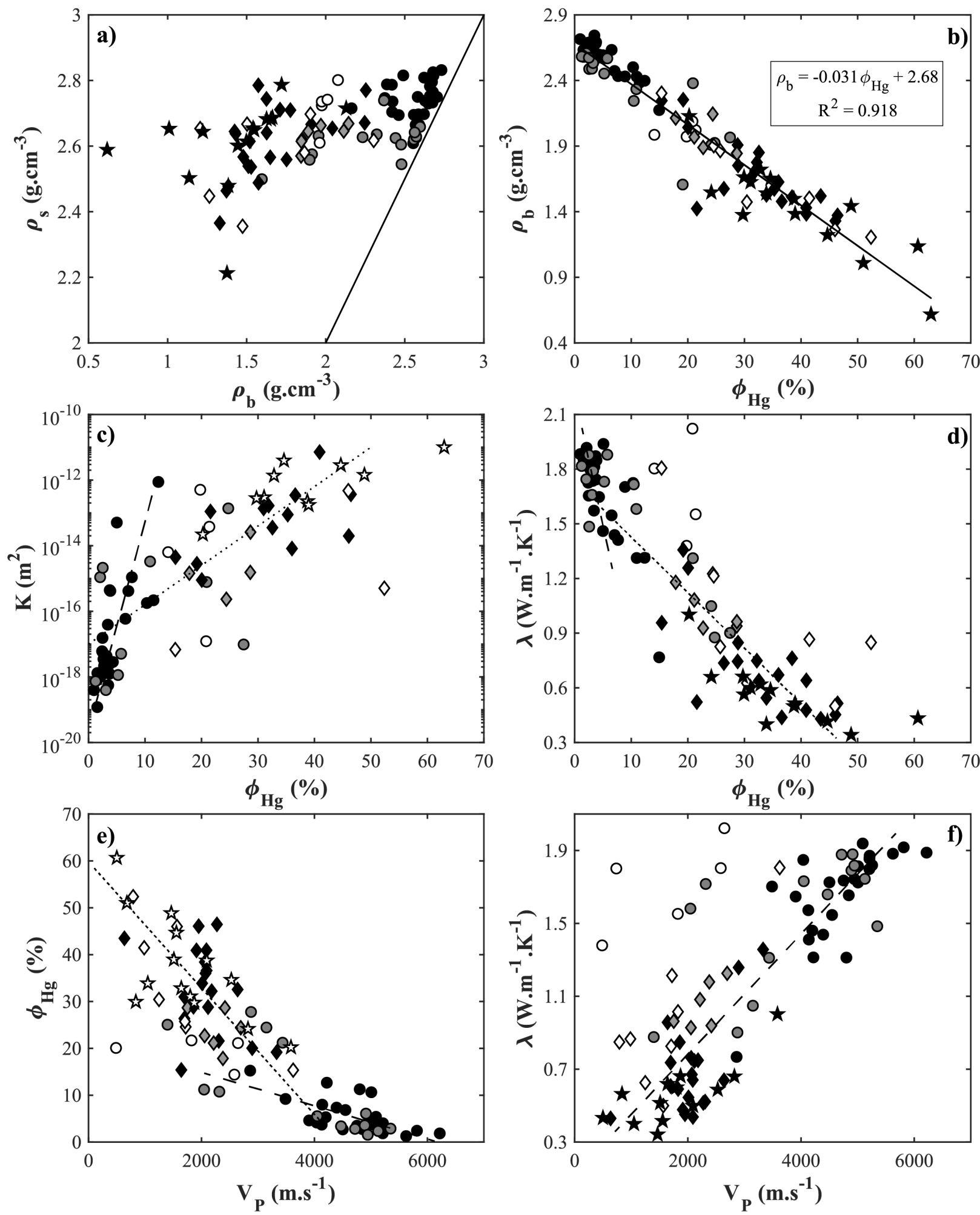

- Fresh lavas $\quad$ Slig. to mod. altered lavas $\bigcirc$ Hydrothermalized lavas $\star$ Fresh pyroclastics

- Fresh debris flows $\diamond$ Slig. to mod. altered debris flows $\diamond$ Hydrothermalized debris flows 
Fig. 8. Thermo-physical rock properties of all investigated lithotypes. a) grain density (gas pycnometer) versus bulk density (triple weighing). b) bulk density versus mercury porosity. c) nitrogen permeability versus mercury porosity. d) thermal conductivity at dry conditions versus mercury porosity. e) Mercury porosity versus compressional wave velocity at dry conditions. f) thermal conductivity versus compressional wave velocity at dry conditions. Average values for each sample. Slig. to mod.: slightly to moderately. (COLOR FOR ONLINE VERSION ONLY / IMAGE SIZE: SMALL COLUMN WIDTH)

High porosity debris flows and pyroclastics have a general lower grain density compared to lavas. Three asumptions could explain this general trend:

- Fresh debris flows and pyroclastics have a dense magnetic mineral content slightly lower than fresh lavas. Indeed, porosities of debris flows and pyroclastics are significantly higher than fresh lavas. Thus, their mineral proportion including magnetic minerals like magnetite, $\rho_{s}=5.2$ (Schön, 2015), is lower.

- On the contrary to entirely crystallized lavas, debris flows are composite rocks with crystallized clasts similar to lava flows embedded in a poorly organized matrix. According to Vallance and Iverson (2015), this clay-rich matrix may result from leaching in hydrothermal systems on volcanic edifice flanks that remove mobile elements and decompose framework silicates to form in particular clay minerals. Clay minerals could trap porosity between clay layers that is not accessible to helium and may be included in the grain density value.

- Last hypothesis remains the existence of a representative elementary volume for debris flows and pyroclastics. This problem is quite inexistent in lavas since the whole rock has a general homogeneity even if fracture and vesicle content may differ on the lava flow profile. On the contrary, a debris flow evolves a lot between its proximal part on the volcano flank to its distal end. It acquires a progressive inverse grading with thin elements at the base and coarse blocks at the top and loads progressively with exotic particles. A downstream sampling at the base of a debris flow leads to a clay content that is not typical of the whole flow. Moreover, our sampling could not take into account clasts coarser than thin pebbles. Cobbles and boulders in debris avalanches and flows were not studied. They are often composed of andesites with lower porosities and higher densities than the matrix of the debris flow. Therefore, the size of debris flow samples used for physical laboratory measurement limits the representativeness of the study to the preponderant matrix part. From these results, if clasts were taken into account, we could infer that the whole porosity of a debris flow might be certainly slightly lower and the grain density slightly higher than our measurements. Taking into account this effect needs a medium scale analysis which is not in the scope of this paper. 


\subsubsection{Permeability vs. porosity}

Permeability measurements (Fig. 8c) exhibit 8 orders of magnitude difference between the lowest and the highest permeable samples. This difference is probably underestimated since a few samples are outside the detection limits of the measurement apparatus $\left(10^{-19}-10^{-11} \mathrm{~m}^{2}\right)$. In accordance with porosity results, pyroclastics and debris flows are more permeable than lavas. Pyroclastics have permeability higher than $10^{-14}$ $\mathrm{m}^{2}$. The relationship between porosity and permeability is not clear and cannot be limited to a simple equation. However, there is a logical increase of permeability with increasing porosity. Two behaviors may be distinguished depending on the porosity value. 1 - Samples with porosities lower than $10 \%$, only represented by lavas, have a steep increase of permeability (dashed line). Samples with the same porosity values span over 2 or 3 orders of magnitude permeability. The pore network is controlled by cracks and the planar organization of elongated vesicles. Cracks improve efficiently the connectivity of initially poorly connected vesicles. Porosity and permeability relationship has a fissural behavior. Fractal equations presented by Pape et al. (1999) were tested but none provided a good correlation coefficient. 2 - Samples with porosity higher than $10 \%$, mostly represented by debris flows and pyroclastics have a gentle slope (dotted line). On the contrary to lavas, matrix porosity is higher than crack and fracture porosity. The increase of permeability with porosity is more limited compared to the first group. It is caused by the higher tortuosity of pore network connecting inter-and intra-particular porosities in pyoclastics and debris flow compared to much straight cracks and elongated vesicles network in lavas.

\subsubsection{Thermal conductivity and P-wave velocity vs. porosity}

Fig. 8d shows an obvious decrease of thermal conductivity with increasing porosity. This relationship could be decomposed in two different linear parts. The first one for lavas (dashed line) has a steep slope caused by a wide range of thermal conductivities $\left(1.4\right.$ to $\left.1.9 \mathrm{~W} \cdot \mathrm{m}^{-1} \cdot \mathrm{K}^{-1}\right)$ in a small range of porosity $(1-7 \%)$. This phenomenon highlights the importance of vesicles acting as isolator on thermal conductivity. The thermal conductivity seems to decrease with increasing vesicle content and elongation. The second one for debris flows and pyroclastics (dotted line) has a gentle slope and a large dispersion on both sides of the linear trend.

A clear decrease of P-waves velocity is observed with increasing porosity (Fig. 8e). The higher and more heterogeneous the porosity is, the lower is the P-wave velocity. For a small range of porosity $(2-5 \%)$, there is a $2500 \mathrm{~m} \cdot \mathrm{s}^{-1}$ range of velocity. This phenomenon is the same that we noticed on Fig. $8 \mathrm{~d}$ for thermal conductivity. 
Good relationships of both thermal conductivity and P-wave velocity with porosity indicate that porosity is the major factor that controls these two properties. However, the difference of few samples with the general trend may results in petrographic heterogeneities or strengths of contacts between minerals in rocks.

\subsubsection{Thermal conductivity vs. P-wave velocity}

Thermal conductivity and P-wave velocity measurements on all dry samples highlight a linear trend. Figure $8 \mathrm{f}$ displays two well-separate groups: lavas with conductivities and velocities generally higher than 1.3 $\mathrm{W} \cdot \mathrm{m}^{-1} \cdot \mathrm{K}^{-1}$ and $3500 \mathrm{~m} \cdot \mathrm{s}^{-1}$ while debris flows and pyroclastics have generally values below these limits. Thermal conductivity and P-waves velocity are directly linked since they principally depend on mineralogy, porosity and the filling of fractures, open or sealed (Mielke et al., 2017). Fresh lavas and the majority of slightly to moderately altered lavas are entirely crystalized and have low porosity, which imply velocities higher than $4000 \mathrm{~m} . \mathrm{s}^{-1}$. However, the development of fracture networks creating porosities higher than $15 \%$ decreases sharply the velocities to values close to volcano-sedimentary deposits. Highly hydrothermalized lavas run completely out of the linear trend. Their P-waves velocities are lower than $3000 \mathrm{~m} \cdot \mathrm{s}^{-1}$ and one sample has a velocity below the detection limit estimated at $500 \mathrm{~m} \cdot \mathrm{s}^{-1}$. This slowness is attributed to three elements: the high dissolution porosity, a large number of micro-cracks, and the almost complete recrystallization of rocks in microlithes of white micas, chlorite, quartz and clay minerals with weak contacts between them. Nevertheless, hydrothermalized lavas have thermal conductivities similar and sometimes higher than fresh lavas. This could be explained by the large amount of pyrite that have a high thermal conductivity (Clauser and Huenges, 1995). Pyroclastics and debris flows have low P-waves velocities and thermal conductivities due to their high interparticular porosity acting as an insulation. Particles of debris flows and pyroclastics are poorly cemented. On the contrary, lavas have an entirely crystallized matrix without glass conferring a good continuity between microlithic groundmass and phenocrysts.

\section{Discussion}

\subsection{Comparison to other published petrophysical data}

Very few studies gathering both petrographic analyses and thermo-physical measurements for these kinds of volcanic rocks are available. To date, no study comparing field measurement and core has been published. However, numerous studies provide very valuable measurements to characterize: 1 - wells in active geothermal fields (Cant et al., 2018; Mielke et al., 2016; Rejeki et al., 2005; Stimac et al., 2004; Wyering et al., 2014); 2 - 
transport properties of pyroclastic rocks (Bernard, 1999; Bernard et al., 2007); 3 - geothermal reservoir potential from outcrop analogue (Lenhardt and Götz, 2015, 2011; Pola et al., 2014, 2012) and 4 - pore network and mechanical properties of andesites (Farquharson et al., 2015; Heap et al., 2015; Heap and Kennedy, 2016). Unfortunately, the comparison of published data on debris flow and pyroclastics with Guadeloupe data is tricky. Indeed, the terminology of volcanic deposits is complex and authors usually name deposits according the process that led to their formations (e.g. indurated block-and-ash flows, Peléean "nuées ardentes", tuff). Usually, they did not characterize physical properties of the ash and pumice matrix but mostly lava blocks which bring no significant information on these deposits since they characterize lava flows too (e.g. Bernard, 1999; Bernard et al., 2007; Heap et al., 2015). Therefore, the comparison with measured properties from Guadeloupe on debris flows and pyroclastics matrix is difficult.

Table 3 summaries major thermo-physical properties published to study geothermal systems: bulk density, porosity, permeability, thermal conductivity, specific heat capacity and compressional wave velocity.

Table 3 Comparison to other published petrophysical data. Outcrop data are either regular character (median values) or italic (mean values). Core measurements are in bold characters (median values). The number of samples are between brackets. Alteration degree: F - fresh; SA - slightly altered; MA - moderately altered; HA - highly altered. References: 1 - Bernard, 1999; 2 - Bernard et al., 2007; 3 - Lenhardt and Götz, 2011; 4 - Lenhardt and Götz, 2015; 5 - Pola et al., 2012 ; 6 - Pola et al., 2014; 7 - Wyering et al., 2014; 8 - Mielke et al., 2015; 9 - Farquharson et al., 2015; 10 - Heap et al., 2015; 11 - Mielke et al., 2016; 12 - Heap and Kennedy, 2016. (IMAGE SIZE: FULL PAGE)

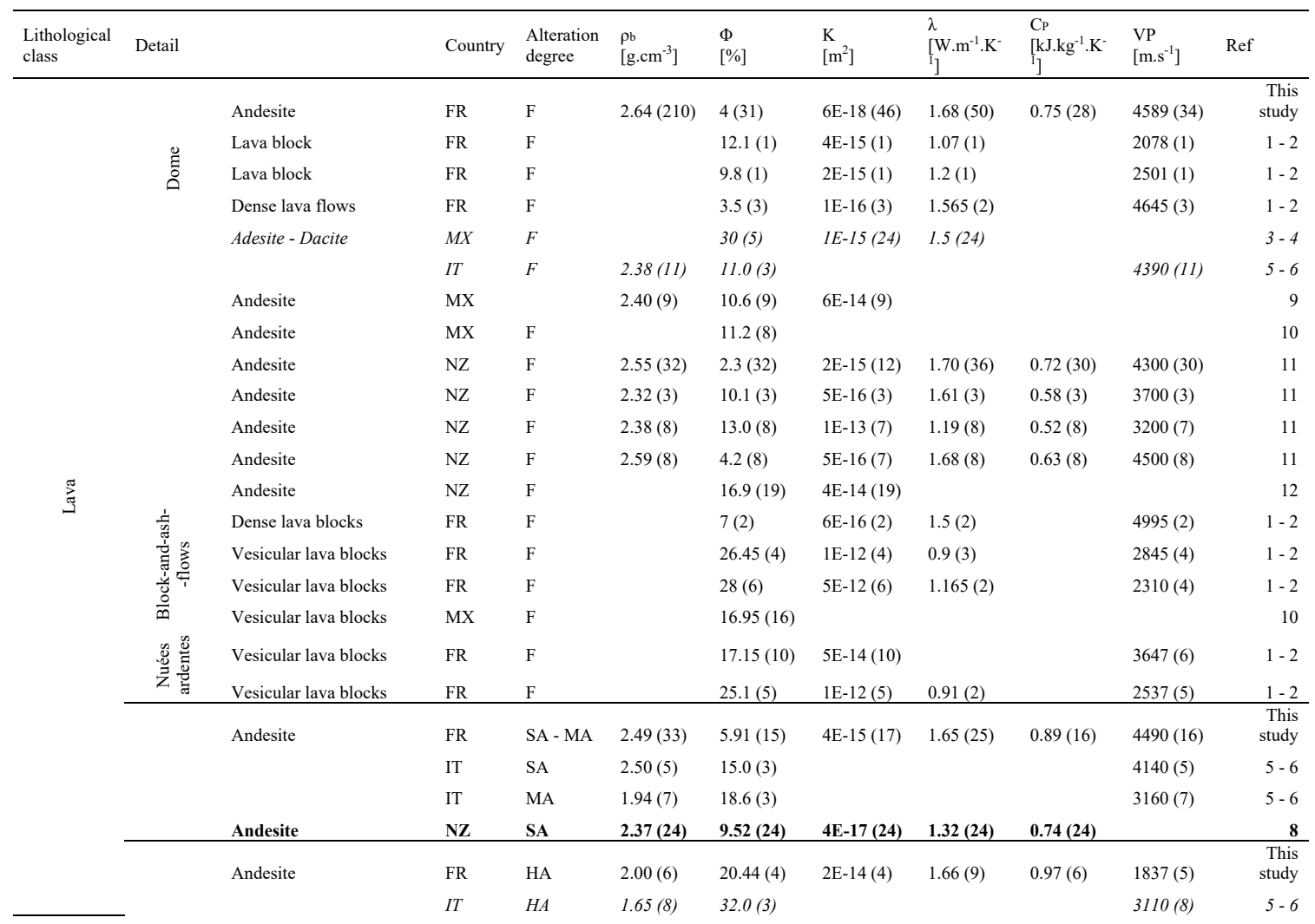




\begin{tabular}{|c|c|c|c|c|c|c|c|c|c|c|c|}
\hline & & & $I T$ & $H A$ & $1.50(7)$ & $26.8(3)$ & & & & $2790(7)$ & $5-6$ \\
\hline & & Andesite & $\mathbf{N Z}$ & SA - HA & $2.53(15)$ & $6.84(15)$ & & & & $4154(15)$ & 7 \\
\hline & & Andesite & MX & HA & & $7.6(7)$ & & & & & 10 \\
\hline & & Andesite & $\mathrm{NZ}$ & HA & & $4.4(8)$ & $5 \mathrm{E}-17(8)$ & & & & 12 \\
\hline \multirow{9}{*}{$\begin{array}{l}3 \\
0 \\
0 \\
0 \\
0 \\
00 \\
0\end{array}$} & & Lahar, Avalanches & FR & $\mathrm{F}$ & $1.63(25)$ & $32.56(21)$ & 4E-14 (16) & $0.67(33)$ & $0.88(22)$ & $2059(23)$ & $\begin{array}{l}\text { This } \\
\text { study }\end{array}$ \\
\hline & & Tuff & $I T$ & $F$ & $1.54(4)$ & $25.5(3)$ & & & & $1140(4)$ & $5-6$ \\
\hline & & Lahar & MX & $\mathrm{F}$ & & $24(7)$ & & & & & 10 \\
\hline & & Lahar, Avalanches & FR & SA - MA & $1.97(7)$ & $23.55(6)$ & $1 \mathrm{E}-15(5)$ & $1.02(12)$ & $0.90(6)$ & $2379(9)$ & $\begin{array}{r}\text { This } \\
\text { study }\end{array}$ \\
\hline & & Lahar, Avalanches & FR & HA & $1.5(7)$ & $30.44(7)$ & $5 \mathrm{E}-16(3)$ & $0.85(11)$ & $0.97(8)$ & $1636(8)$ & $\begin{array}{r}\text { This } \\
\text { study }\end{array}$ \\
\hline & & $\begin{array}{l}\text { Tuff breccia } \\
\text { Mass flow deposits }\end{array}$ & $M X$ & $H A$ & & $15.2(5)$ & $2 E-14(5)$ & $0.8(6)$ & & & $3-4$ \\
\hline & & Tuff & $I T$ & $H A$ & $1.81(3)$ & $29.7(3)$ & & & & $2250(3)$ & $5-6$ \\
\hline & & Andesite breccia & $\mathbf{N Z}$ & HA & $2.66(12)$ & $1.68(12)$ & & & & $4163(12)$ & 7 \\
\hline & & Andesite breccia & $\mathrm{NZ}$ & HA & $1.71(12)$ & 38.67 (12) & 1E-15 (12) & $0.72(12)$ & $0.66(12)$ & & 8 \\
\hline \multirow{18}{*}{ 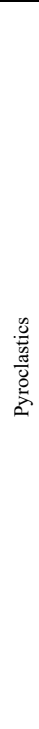 } & & Scoria, Pumice and Ashes & FR & $\mathrm{F}$ & $1.52(20)$ & $34.24(16)$ & $8 E-13(10)$ & $0.54(25)$ & $0.88(15)$ & $1642(17)$ & $\begin{array}{r}\text { This } \\
\text { study }\end{array}$ \\
\hline & & $\begin{array}{l}\text { Block-and-ash flow } \\
\text { Indurated ashes }\end{array}$ & FR & F & & $13.9(6)$ & $6 \mathrm{E}-15(6)$ & $1.33(2)$ & & $3970(5)$ & $1-2$ \\
\hline & & Scoriaceous blocks & FR & F & & $35.2(3)$ & $2 \mathrm{E}-12(3)$ & $0.57(3)$ & & $3421(3)$ & $1-2$ \\
\hline & & Pumices & FR & F & & $57.4(7)$ & $8 \mathrm{E}-13(6)$ & & & $1986(5)$ & $1-2$ \\
\hline & & Scoria & MX & & $1.43(4)$ & 46.7 (4) & $4 \mathrm{E}-13(4)$ & & & & 9 \\
\hline & & Pumice & MX & & $1.07(4)$ & $58.25(4)$ & $2 \mathrm{E}-12(4)$ & & & & 9 \\
\hline & & Scoria & $\mathrm{NZ}$ & & & $60.9(2)$ & $3 \mathrm{E}-11(2)$ & & & & 12 \\
\hline & \multirow{11}{*}{ 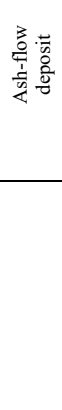 } & Incipiently welded & $M X$ & $S A$ & & $37.7(7)$ & $5 E-15(7)$ & $0.5(5)$ & & & $3-4$ \\
\hline & & Partially welded & $M X$ & $S A$ & & $33.0(25)$ & $6 E-14(25)$ & $0.6(17)$ & & & $3-4$ \\
\hline & & Moderately welded & $M X$ & $S A$ & & $21.3(29)$ & $2 E-14(29)$ & 0.9 (33) & & & $3-4$ \\
\hline & & Densely welded & $M X$ & $S A$ & & $1.6(6)$ & $4 E-16(6)$ & $1.7(13)$ & & & $3-4$ \\
\hline & & Ignimbrite & $I T$ & $S A$ & $0.98(13)$ & $65.0(3)$ & & & & $1140(13)$ & $5-6$ \\
\hline & & Ash tuffs & $\mathbf{N Z}$ & SA - HA & $1.57(125)$ & $\begin{array}{l}40.56 \\
(125)\end{array}$ & $\begin{array}{l}3 E-14 \\
(125)\end{array}$ & $0.79(125)$ & $0.63(125)$ & & 8 \\
\hline & & Ignimbrite & $\mathbf{N Z}$ & HA & $2.35(37)$ & $10.90(37)$ & & & & 3489 (36) & 7 \\
\hline & & Pyroclastic & $I T$ & $H A$ & $1.48(8)$ & $41.5(3)$ & & & & $2180(8)$ & $5-6$ \\
\hline & & Pyroclastic & $I T$ & $H A$ & $1.54(9)$ & $44.8(3)$ & & & & $2060(9)$ & $5-6$ \\
\hline & & Pyroclastic & $I T$ & $H A$ & $1.43(7)$ & & & & & $1650(7)$ & $5-6$ \\
\hline & & Tuffs & NZ & HA & $2.12(10)$ & $17.64(10)$ & & & & $2798(10)$ & 7 \\
\hline
\end{tabular}

Authors extensively studied lava flows and lava blocks from block-and-ash flows. It may be explained by easier measurements on lavas than on lower cohesion pyroclastics and debris flows (e.g. Bernard et al., 2007; Lenhardt and Götz, 2011; Mielke et al., 2016). Fresh lavas from Guadeloupe are mostly dense. Therefore, they have generally lower porosity and matrix permeability compared to vesiculated blocks from Martinique. A local comparison with dense lavas from Montagne Pelée (Martinique) displays similarities for porosity (Bernard et al., 2007). Farquharson et al. (2015), Heap et al. (2015), Heap and Kennedy (2016) worked on andesite stratovolcanoes either on Volcán de Colima (Mexico) or Mt. Ruapehu (New Zealand) studying porosity-permeability relationships and mechanical behavior of andesite rocks. They measured higher porosities (10.6 - 17\%) for lavas explaining 3 to 4 orders of magnitude higher permeability. On the contrary andesite affected by high temperature alteration have surprisingly lower porosity and permeability, respectively $4.4 \%$ and $5.10^{-17} \mathrm{~m}^{2}$. For the same porosities, Guadeloupe and New-Zealand lavas have approximately the same thermal conductivities and compressionnal wave velocities $(4-2.3-4.2 \%, 1.68-$ $1.70-1.68 \mathrm{~W} \cdot \mathrm{m}^{-1} \cdot \mathrm{K}^{-1}, 4589-4300-4500 \mathrm{~m} \cdot \mathrm{s}^{-1}$; Mielke et al., 2016). Lavas with higher porosities display 
significant decreases of thermal conductivity and P-waves velocities (Mielke et al., 2016). It confirms that thermal conductivity and compressional wave velocity are mainly controlled by porosity and the structure of pore network. However, Mielke et al. (2015), observed in the Tauhara geothermal field a decrease of porosity and permeability with increasing depth consecutively with advancing hydrothermal alteration. On the contrary, Guadeloupe lavas display an increase of porosity and permeability with advancing hydrothermal alteration. In Gudaloupe, the increase of microcrack density in altered lavas and the replacement process of plagioclases and pyroxenes by more porous minerals are the dominant features whereas primary porosity clogging is of less importance. A similar feature was observed in Solfatara (Italy - Pola et al., 2012) where hydrothermal alteration progressively increases porosity. Pola et al. (2012) highlighted a slight decrease of porosity in totally altered lava related to large pores filled by new minerals.

Both fresh Debris flows from Guadeloupe and Ischia tuff (Italy - Pola et al., 2012) have porosities higher than $25 \%$. Hydrothermal alteration tends to maintain this value to approximately $30 \%$ and slightly decreases permabilities around $10^{-15}-10^{-16} \mathrm{~m}^{2}$ (Mielke et al., 2015; Pola et al., 2012). New minerals formed in large primary pores reducing pore throat diameters may explain this one order of magnitude decrease of permeability.

Overall, fresh pyroclastics from Guadeloupe exhibit lower porosities (34\%) and permeability $\left(8.10^{-13} \mathrm{~m}^{2}\right)$ than scoria and pumice from Volcán de Colima and Montagne Pelée. A major drop of these properties was observed by Lenhardt and Götz (2011) in slightly altered densely welded ash-flow deposit. Only few data are available for highly altered pyroclastics but core data display porosity higher than $10 \%$, permeability around $10^{-14} \mathrm{~m}^{2}$ with thermal conductivity half as high than lavas (Mielke et al., 2015; Wyering et al., 2014). Highly altered outcropping pyroclasic sequence from Solfatara (Pola et al., 2012) has a porosity above $40 \%$. Such porosities and permeabilities measured on ouctrop and cores show that pore collapse in pyroclastics does not totally close pores.

To conclude, the comparison of outcrop data and core data exhibits large similarities. Advanced hydrothermal alteration improves porosity and permeability of lavas and unchanged or reduced these properties in pyroclastics and debris flows. Altered samples have mostly porosities higher than $20 \%$ and permeabilies comprised between $10^{-14}$ and $10^{-16} \mathrm{~m}^{2}$. However, these properties were only measured on matrix at a small scale. Thus, at a larger scale, the major role of fractures and faults on hydrothermal fluid flow and storage (Cox et al., 2015; Cox, 2010; Faulkner et al., 2010; Micklethwaite et al., 2015; Pinti et al., 2017; Rowland and Sibson, 2004; Rowland and Simmons, 2012; Scibek et al., 2016; Sibson, 1996, 1994; Sibson and 
Rowland, 2003; Simpson and Bignall, 2016; Tardani et al., 2016; Wilson and Rowland, 2016) was not taken into account.

\subsection{Storage and fluid flow properties in a lava flow}

Section 4.2.3 highlighted a wide variability of porosity and permeability especially for lava flows (Fig. 8c). To illustrate this heterogeneity and discuss the evolution of storage and fluid flow properties within a lava flow, petrophysical properties of four samples coming from the Pointe de l'Anse lava flow were isolated (Fig. 9). Four layers are visible on a $1.5 \times 1.5 \mathrm{~m}$ outcrop section. From bottom to top: a $20 \mathrm{~cm}$ thick vesicular layer with centimeter size widely open elongated vesicles; a $50 \mathrm{~cm}$ layer with thin bubble vesicles and half meter fractures; a $20 \mathrm{~cm}$ thick connected spherical vesicle rich layer and a $60 \mathrm{~cm}$ thick layer with regularly spaced planar cooling joints. This structure in sub-parallel planar layers having different contents of vesicles and densities of fractures creates a strong vertical anisotropy (Yi et al., 2015).

Results show a wide dispersion of matrix porosity $(2.5-12.5 \%)$ and a 5 orders of magnitude difference of permeability $\left(10^{-17}-10^{-12} \mathrm{~m}^{2}\right)$. The comparison of permeability measurement performed parallel and perpendicular to magmatic foliation (Fig. 9) highlights that vesicles predominantly control the anisotropy of matrix permeability. This is confirmed by the lowest porous and permeable sample, which is the only isotropic sample for permeability. Thermal conductivity and P-wave velocity exhibit the same anisotropy since areas with vesicles create a large decrease of the two properties. Only one sample has better thermal conductivity and P-wave velocity perpendicular than parallel to magmatic foliation. For this sample, the vertical fracture corridor creates a larger decrease of both properties than the vesicle plane. At the matrix scale, these results show that lavas have poor reservoir properties. However, at a larger scale several geothermal, groundwater and hydrocarbon reservoirs are hosted in lava flows (Feng, 2008; Hadi et al., 2005; Wang and Chen, 2015). The Rotokawa geothermal reservoir in New Zealand is composed of altered andesites with low porosity and the fluid flow is structurally controlled (Siratovich et al., 2014). Besides, Murphy et al. (2004) show that high permeability natural fractures have a predominant role in fluid flow compared to the surrounding rock matrix. The occurrence of columnar cooling joints in lavas provides high permeability pathways (Rowland and Sibson, 2004), which could decrease the anisotropy caused by vesicles aligned along magmatic foliation.

The Pointe de l'Anse lava flow contains mostly planar joints and vertical columnar joints. A striking feature is the difference in the number of planar fractures in the different layers. The density of fractures varies inversely with the vesicle content. Cooling joints are mostly concentrated in vesicle-poor layer. Vesicles tend 
to abort brittle behavior. They are transformed by ductile behavior during cooling, which explains their elongated shapes and allows a better connection of pore network increasing permeability. Preferential hydrothermal fluid flow in lava flows should occur both in vesicle layers and cooling joints during burial.
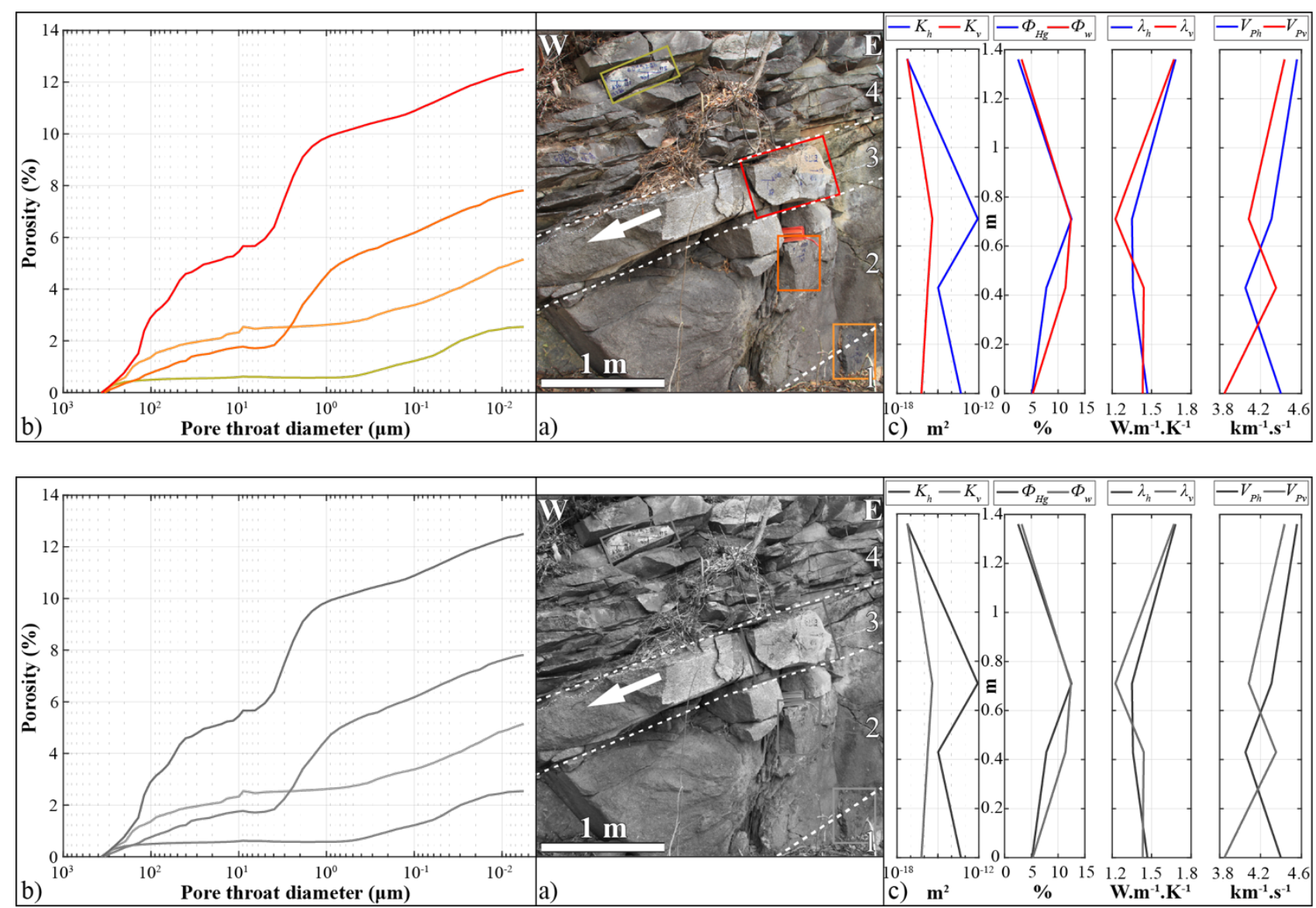

Fig. 9. Profile of measured physical properties on 4 samples coming from the same lava flow in Pointe de l'Anse (location on Fig. 1e). a) picture of the outcropping lava flow with the location of samples (insets). Dashed lines limit the 4 different zones in the lava flow: 1 - elongated vesicle rich layer; 2 - vertically fractured layer with thin spherical vesicles; 3 - vuggy vesicle rich layer and 4 - densely fractured zone without vesicles. The white arrow indicates the direction of magma flow. b) mercury injection curves. c) 4 plots summarize principal physical properties. Permeability, thermal conductivity and P-wave velocity are measured parallel and perpendicular to magmatic foliation. The second plot displays porosity measurements using mercury injection and triple weighing method. (COLOR FOR ONLINE VERSION ONLY / IMAGE SIZE: FULL PAGE)

\subsection{General impact of alteration on thermo-physical properties}

Cross-plots of physical properties of studied rocks (Fig. 8) highlighted the large variability of thermophysical parameters. Two trends are clearly distinguishable on every plot between fresh lava flows on one side and fresh debris flows and pyroclastics on the other. Altered samples form an intermediary group. Advancing alteration tends to decrease initial thermo-physical differences between fresh rock types. Fresh pyroclastics and debris flows have high intergranular porosity with large pore throat diameter resulting in a strong 
permeability. Fluids can easily flow into the matrix to transform initial minerals to secondary minerals thanks to hydrothermal alteration. It could results in a patchy alteration depending on the nature of clasts (Mielke et al., 2015). Lava clasts tend to be less altered than the fine-grained matrix (Fig. 10a) on the contrary to porous pumice clasts. At a small scale, matrix of fresh lava flows has poor fluid flow properties compared to debris flows and pyroclastics, even if it is affected by microcracks. It limits the development of pervasive alteration. Fortunately, lava flows are affected by dense networks of cooling joints, which are either approximately parallel or perpendicular to magmatic foliation (Aydin and Degraff, 1988; Degraff and Aydin, 1993; Massiot et al., 2017; Mathieu, 2010). Joints divide lava flow body into a large number of geometric blocks with shape depending on the orientation of joints. Therefore, the lava flow should not be considered as a unique massive body but as multiple few decimeters size blocks limited by fractures. Intersections of joints create a large number of preferential pathways for fluid entering in the lava (Figs. 10b-c). Lava flows form a quasi-porous medium at the medium to large scale and can act as an aquifer whereas matrix of small blocks has very low permeabilities. Very rare lava flows are affected by spheroidal weathering. Fluids flowing in joints progressively propagate to low permeable and porous matrix creating "onion skin" fractures (Jamtveit et al., 2009, 2008) separating a fresh core from an altered multi-layer rind (Sak et al., 2010). Fractures appearing by spalling divide lava blocks into thin layers with improved porosity and permeability. Therefore, the lava may be easily transformed by hydrothermal alteration during burial.

A long-term circulation of hydrothermal fluids tends to completely transform matrix of every lithotypes. Hydrothermal alteration transforms initial minerals into secondary phases like clay minerals with lower thermal conductivity (Clauser and Huenges, 1995) and compressional wave velocity (Schön, 2015). These neoformed minerals fill initial vesicles of lavas and inter-particular porosity of debris flow and pyroclastics reducing pore throat diameters (Fig. 7). A secondary porosity appears due to the replacement of low porosity plagioclase and pyroxene by high porosity clays minerals and the development of microcracks with increase of temperatures ("thermal cracking", Mielke et al., 2016). The new porosity has lower pore throat diameters and form a more homogenous pore network. Highly altered pyroclastics do not outcrop in Guadeloupe so it is difficult to predict if their large open pores collapse with overburden pressure and hydrothermal alteration. Rejeki et al. (2005) measured porosities in lapilli between $10-15 \%$ at a $7000 \mathrm{ft}$ depth in the Darajat geothermal field. Mielke et al. (2015) observed a permeability increase in ash tuff by a few percent with advancing hydrothermal alteration in the Tauhara geothermal field. Moreover, published cross section of active 
Bouillante (Lachassagne et al., 2009; Mas et al., 2006) and Lahendong (Indonesia - Brehme et al., 2014) geothermal fields localized production zones in tuff, lahars and volcanic breccia and secondary permeable zones in massive lavas. Therefore, hydrothermal alteration and overburden pressure are not sufficient to close pore network of pyroclastics and debris flows which could actively act as aquifer.
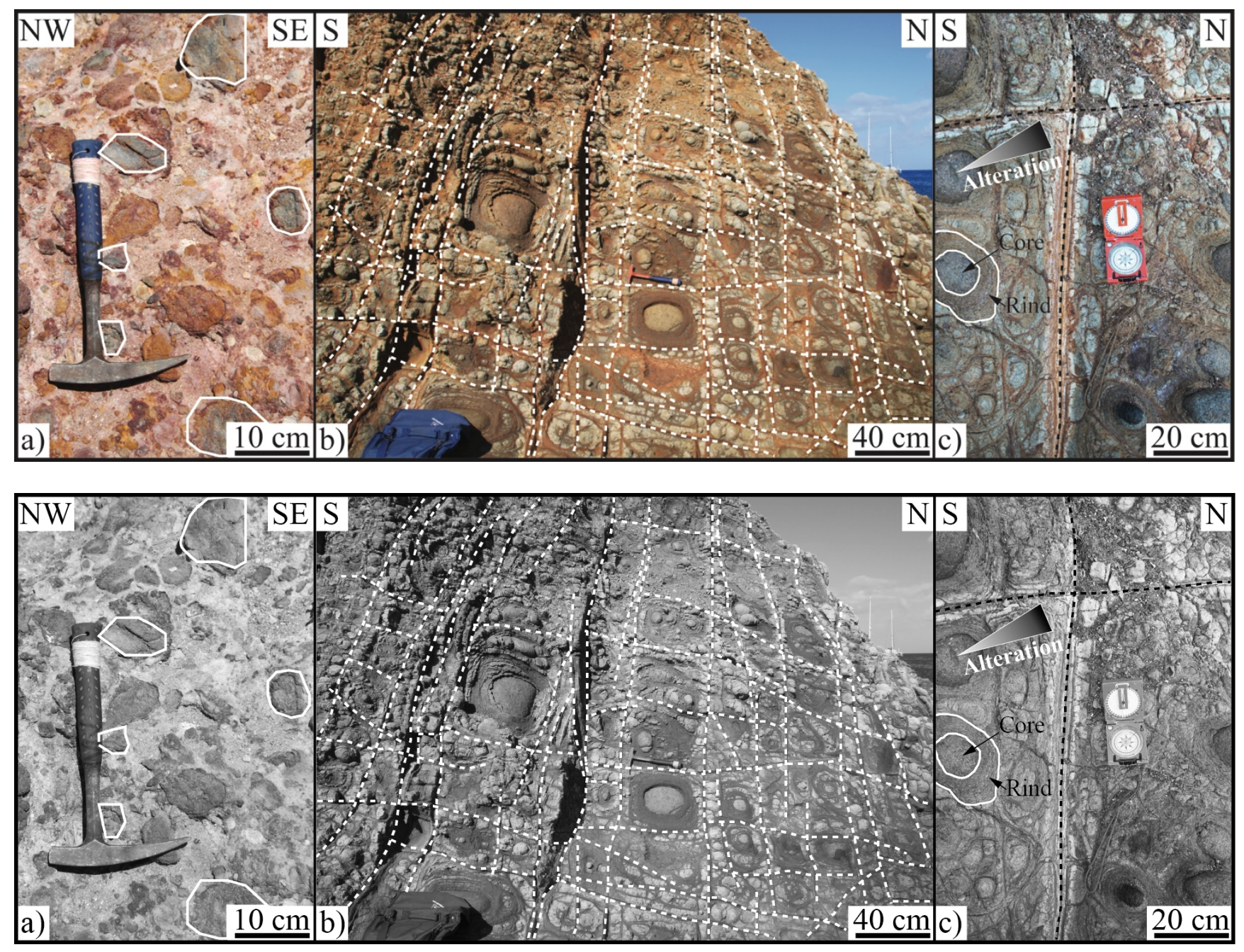

Fig. 10. Alteration of debris flow and lava flow. a) Differential alteration in a coarse debris flow from the Rocroy beach (location Fig. 1e). Slightly hydrothermalized andesitic blocks are included in a whitish to reddish highly hydrothermalized matrix where initial minerals are totally transformed. $b$ and c) Spheroidal weathering in Tête Rouge La Batterie lava flow (Fig. 1f). The lava flow is cut by a set of sub-horizontal and vertical joints, which divide the lava flow in cubic blocks of andesites typically around few decimeters size. Every block is affected by "onion-skin" fractures separating a "fresh" core from an altered rind. The rusty colored striation is a combination of Liesegang bands and "onion-skin" fractures (Jamtveit et al., 2011). The preferential fluid circulation from joints toward andesite block interior creates a gradual alteration degree improved by intersection of closely spaced joints. (COLOR FOR ONLINE VERSION ONLY / IMAGE SIZE: FULL PAGE)

\subsection{Reflection on a model of the geothermal system in Guadeloupe}

Measurement of physical parameters and understanding of the impact of advancing hydrothermal alteration allow proposing a first explanation of the development of a geothermal system in active volcanic 
islands like Basse-Terre (Fig. 11). We propose a brief scenario in several steps to explain transformation of fresh volcanic rocks into highly altered rocks:

1 - The relative rich content of silica produced mainly andesite lava (Fig. 3). Field observations exhibit that lavas are mainly located close to the emission center. The proportion of lavas progressively decreases toward the island coast. A cross section of the island between emission center and the coast is composed by an alternation of lavas, debris flows, pyroclastics and debris avalanches (Fig. 4). This alternation of lithotypes creates a major planar anisotropy perpendicular to the volcano flank decreasing notably the vertical permeability. However, it is compensated by dykes and faults cross cutting the layering of lithotypes (Rowland and Sibson, 2004; Scibek et al., 2016). The viscous magma is favorable for the development of unstable steep flanks responsible for debris avalanches with meter size blocks and explosive volcanism resulting in high amounts of pyroclastic material (Boudon et al., 2008) deposited on the volcano slopes respectively (Fig. 11, stage 0);

2 - The tropical climate with several meters rainfalls per year on summit generate a high hydraulic gradient between the volcano summit and the coast. Deposits linked with explosive volcanism (ash and pumice, blocks, bombs...) are saturated with water and may be reworked later into debris flows on the volcano slopes. Pyroclastics and debris flows are loaded with meteoric water on the volcano flanks thanks to their suitable physical properties (Fig. 11, stage 1). Since lavas are surrounded by formations saturated with fluid, water progressively infiltrates lavas along cooling joints, auto-brecciated and vesicular areas;

3 - When all lithotypes are buried under new volcanic materials (Fig. 11, stage 2), they are placed into high temperature (higher than $200^{\circ} \mathrm{C}$ ) at shallow depth due to abnormal temperature gradient (Manga et al., 2012) and low overburden pressure. This is proved by the presence of high temperature neoformed minerals in altered rocks of the exhumed geothermal system in Terre-de-Haut (muscovite, epidote, Figs. 5c and 5f). According to lithium isotopic measurements, (Millot et al., 2010) demonstrated a mixing zone of meteoric water and seawater located below the transition zone between andesite volcanic flows and basaltic dikes. This zone would be situated at a depth ranging from 3 to $5 \mathrm{~km}$. The resulting fluid is transported vertically by faults creating convections cells (Bouchot et al., 2008). The tectonic context is ideal because major structures have different orientations (e.g. Calcagno et al., 2012) creating a lot of fault intersections suitable for fluid ascent. Moreover, these faults may be well connected to fractured lavas improving the large-scale porosity and 
permeability of the system. Therefore, the resulting hot fluid flows from faults to highly-fractured lavas and high matrix porosity lithotypes initiating the transformation of initial minerals (Fig. 5);

4 - Burial of volcanic lithotypes carries on (Fig. 11, stage 3). Overburden pressure is supposed to decrease the size of large pores in debris flows and pyroclastics but it could be partly compensated by the fluid pressure (Traineau et al., 2014). Porosity of all lithotypes is filled with hot hydrothermal fluid. According to temperature profile acquired in production wells, the temperature of fluid hits $240-260^{\circ} \mathrm{C}$ and stays unchanged at depths ranging between 500 and $1800 \mathrm{~m}$ (Bouchot et al., 2010, 2008; Mas et al., 2006; Sanjuan et al., 2004, 2000). Transformations of initial minerals in pyroclastics and debris flows slightly decrease their porosities and permeabilities but increase their thermal conductivity. Replacement processes induce fractures and cracks in lavas (Jamtveit et al., 2009) significantly increasing reacting surfaces, porosity and permeability even if vesicles are progressively sealed by clay minerals. Published well logs of the Bouillante field (Sanjuan et al., 2004) allow to rank production area : 1 - a major production in highly fractured areas, but the corresponding lithotypes is not described because of total loss; 2 - a medium production in tuffs and finally 3 - a minor production in lavas.

The circulation of hydrothermal fluid contributes to the total replacement of initial minerals However, field evidences in the exhumed geothermal system show that lavas are less transformed than debris flows certainly because their matrix is less permeable. Indeed, the highly hydrothermalized Grande Anse cliffs (Terre-de-Haut Island) exhibit a vertical succession of lavas and debris flows where limits between lithotypes are still well marked: debris flows are totally transformed whereas lavas have preserved their initial structure. Therefore, the initial anisotropy linked with initial volcanic deposits persists during the activity of the geothermal system;

5 - Several reasons may explain the end of the geothermal system like the migration of volcanic activity or development of new major faults transporting hydrothermal fluid elsewhere. Erosion of the volcanic chain contributes to exhume the geothermal system (Fig. 11, exhumed stage). Field evidences in the central part of Terre-de-Haut highlight that final stage of the cooling geothermal system before exhumation consists in the partial filling of fractures and bedding by a large amount of gypsum, pyrite and calcite (Fig. 2f and Fig. 11, exhumed stage, pink veins). Gypsum veins are predominantly located in highly altered debris flows indicating the preservation of high porosity and permeability of debris flows in the reservoir. Finally, weathering may 
occur on exhumed rocks. XRD analyses displayed a low kaolinite content showing that weathering of altered rocks is very limited. 


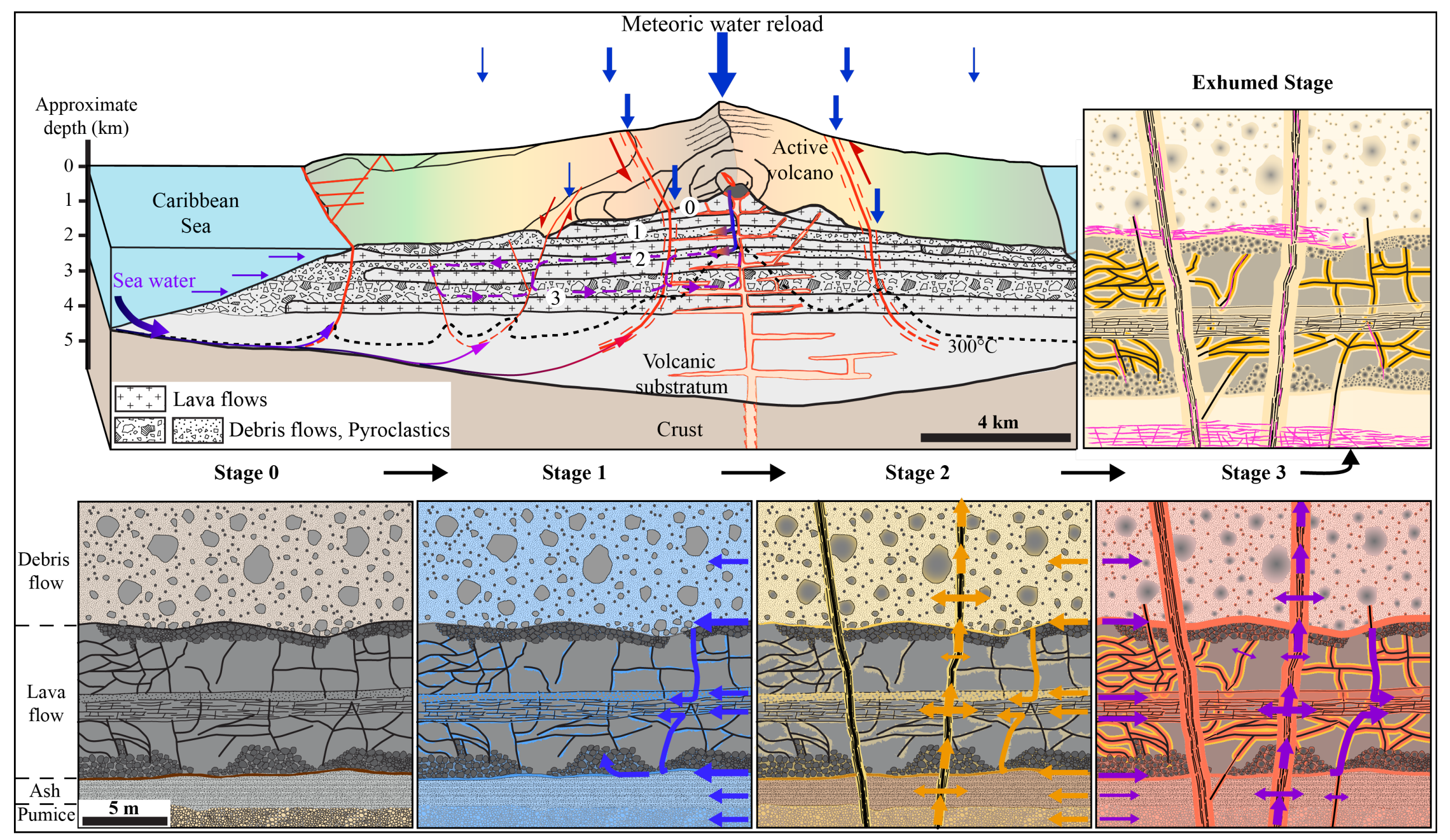


Fig. 11. Conceptual geological model of a geothermal system in Basse-Terre Island. The width of volcanic deposits was increased in the model to improve the visibility, but the size of deposits is respected in every zoom areas for a $50 \mathrm{~m}$ thick volcano lithostratigraphical single unit. Stage 0 - General organization of fresh deposits after a pulse of volcanic activity of the stratovolcano. Stage 1 - Saturation of primary porosity with meteoric water on the volcano flank. Size of arrows is proportional to fluid flow. Stage 2 - Tectonic constraints induce fractures and faults crossing deposits. A mix of seawater and meteoric water replaces meteoric water thanks to major faults. The resulting fluid impregnates all deposits and initial mineral replacement begins. Stage 3 - Volcanic lithotypes are buried between 500 and $2000 \mathrm{~m}$. The temperature of fluid $\left(\approx 250{ }^{\circ} \mathrm{C}\right)$ increases the velocity of mineral transformation. Contacts between volcano-sedimentary units and lava flow are preferential pathways for fluids. Initial cooling joints are extended till neighbor joints to form continuous structures. Stage 4 - Hydrothermally transformed lithotypes are exhumed due to volcano erosion. Exhumation of the geothermal system partly fills fractures with gypsum, pyrite and gypsum. (COLOR FOR ONLINE VERSION ONLY / IMAGE

\section{SIZE: FULL PAGE)}

\section{Conclusion}

The presented study provides a dataset of thermo-physical properties for rocks of andesitic composition formed by explosive and effusive volcanism. Studied lithotypes are: 1 - lava flows with different vesicle content; 2 - coarse breccia mostly composed of debris flows and 3 - pyroclastics including ash, pumice and scoria. Every lithological class was divided according to alteration advancement. This work on both fresh and hydrothermalized data is a cheap and effective way to face the lack of deep information brought by exploration wells, which are not available in the interest area. The dataset comprises following measurements on matrix: bulk and grain densities, mercury, water and helium porosities, permeability, P-wave velocity, thermal conductivity and diffusivity and finally calculation of specific heat capacity. These parameters are essential to build realistic reservoir models to evaluate the resource potential in the Vieux-Habitants area.

The study exhibits large heterogeneities between the different lithotypes and identifies clear boundaries separating lavas, pyroclastics and debris flows. At a small scale, fresh lavas have low porosity and permeability but high thermal conductivity whereas the opposite features are noticed in debris flows and pyroclastics. Field observations revealed a very distinct mechanical behavior with high density fractures in lavas partially caused by cooling and localized fracture corridors in pyroclastics and debris flows. High density cooling joints in lavas result in a significant improvement of porosity and permeability at a larger scale.

The impacts of hydrothermal alteration are: 1- a disappearance of highly magnetic minerals resulting in rocks without magnetic signal, which could improve the prospection of geothermal fields by geophysics and 2 - a general replacement of primary minerals by secondary phases that totally modify the initial pore network reducing pore throat diameters. The impact of alteration on thermo-physical properties is contrasted for lava 
and debris flows since it produces an increase of porosity and permeability of lavas and a decrease in debris flows. Thermal conductivity stays constant in lavas whereas it increases significantly in debris flows due to partial clogging of inter particular porosity.

Finally, comparison with other published data and especially the work of Mielke et al. $(2016,2015)$, Pola et al. (2012), Siratovich et al. (2014) demonstrated remarkable correlations between thermo-physical properties acquired from outcrops samples and cores from geothermal fields. Therefore, outcrop measurement of altered samples should be considered at least to a first approximation as representative of deep rocks.

\section{Acknowledgements}

The authors would like to thank the GEOTREF project for financial support (www.geotref.com). This project is funded by ADEME in the frame of les Investissements d'Avenir program. Partners of the GEOTREF project are Teranov, Kidova, Mines ParisTech, ENS Paris, GeoAzur, Georessources, IMFT, IPGS, LHyGes, UAG, UCP-GEC. 


\section{References}

Andreieff, P., Bouysse, P., Westercamp, D., 1979. Reconnaissance géologique de l'arc insulaire des Petites Antilles. Résultats d'une campagne à la mer de prélèvements de roches entre Sainte-Lucie et Anguilla (No. 80SGN086MAR). Bureau de Recherches Géologiques et Minières.

Aretz, A., Baer, K., Götz, A., Sass, I., 2015. Outcrop analogue study of Permocarboniferous geothermal sandstone reservoir formations (northern Upper Rhine Graben, Germany): impact of mineral content, depositional environment and diagenesis on petrophysical properties. https://doi.org/10.1007/s00531-015$1263-2$

Aydin, A., Degraff, J.M., 1988. Evoluton of Polygonal Fracture Patterns in Lava Flows. Science 239, 471476. https://doi.org/10.1126/science.239.4839.471

Bas, M.J.L., Maitre, R.W.L., Streckeisen, A., Zanettin, B., 1986. A Chemical Classification of Volcanic Rocks Based on the Total Alkali-Silica Diagram. J Petrology 27, 745-750. https://doi.org/10.1093/petrology/27.3.745

Bazin, S., Feuillet, N., Duclos, C., Crawford, W., Nercessian, A., Bengoubou-Valerius, M., Beauducel, F., Singh, S.C., 2010. The 2004-2005 Les Saintes (French West Indies) seismic aftershock sequence observed with ocean bottom seismometers. Tectonophysics 489, 91-103. https://doi.org/10.1016/j.tecto.2010.04.005

Belghoul, A., 2007. Caractérisation pétrophysique et hydrodynamique du socle cristallin (French). Université de Montpellier 2 Sciences et Techniques du Languedoc, Montpellier.

Bernard, M.-L., 1999. Etude expérimentale des propriétés physiques des roches pyroclastiques de la Montagne Pelée (French). Université de Paris 07, France.

Bernard, M.-L., Zamora, M., Géraud, Y., Boudon, G., 2007. Transport properties of pyroclastic rocks from Montagne Pelée volcano (Martinique, Lesser Antilles). J. Geophys. Res. 112, B05205. https://doi.org/10.1029/2006JB004385

Bertani, R., 2016. Geothermal power generation in the world 2010-2014 update report. Geothermics 60, 31-43. https://doi.org/10.1016/j.geothermics.2015.11.003

Bertrand, L., 2017. Etude des réservoirs géothermiques développés dans le socle et à l'interface avec les formations sédimentaires. Université de Lorraine.

Bézèlgues-Courtade, S., Bes-de-Berc, S., 2007. Inventaire et caractérisation des sources thermales de Guadeloupe (No. BRGM/RP-55060-FR).

Blanc, F., 1983. Corrélations chronologiques et géochimiques des formations volcaniques du sud de la basse terre de Guadeloupe (petites Antilles) : début du cycle récent (phdthesis). Université Scientifique et Médicale de Grenoble.

Bossennec, C., Géraud, Y., Moretti, I., Mattioni, L., Stemmelen, D., 2018. Pore network properties of sandstones in a fault damage zone. Journal of Structural Geology 110, 24-44. https://doi.org/10.1016/j.jsg.2018.02.003

Bouchot, V., Sanjuan, B., Calcagno, P., Gloaguen, E., Thinon, I., Gailler, L., Baltassat, J.-M., Bourgeois, B., Lerouge, C., Gadalia, A., Bourdon, E., Traineau, H., Patrier-Mas, P., Beaufort, D., Verati, C., 2011. The High-Temperature Geothermal System of Bouillante (Guadeloupe, French West Indies), in: 19ème Conférence Géologique de La Caraibe 2011. Le Gosier, Guadeloupe, France.

Bouchot, V., Traineau, H., Guillou-Frottier, L., Thinon, I., Baltassat, J.-M., Fabriol, H., Bourgeois, B., Lasne, E., 2010. Assessment of the Bouillante Geothermal Field (Guadeloupe, French West Indies): Toward a Conceptual Model of the High Temperature Geothermal System. Presented at the World Geothermal Congress 2010, p. 8 p.

Bouchot, V., Traineau, H., Sanjuan, B., Gadalia, A., Guillou-Frottier, L., Thinon, I., Fabriol, H., Bourgeois, B., Baltassat, J.-M., Pajot, G., Jousset, P., Lasne, E., Genter, A., 2008. Modèle conceptuel du champ géothermique haute température de Bouillante, Guadeloupe, Antilles françaises. Rapport final. (Rapport BRGM No. RP-57252-FR). BRGM.

Boudon, G., 1988. Carte géologique du massif volcanique de la Soufrière (Département de la Guadeloupe, Petites Antilles). [WWW Document].

Boudon, G., Komorowski, J.-C., Villemant, B., Semet, M.P., 2008. A new scenario for the last magmatic eruption of La Soufrière of Guadeloupe (Lesser Antilles) in 1530 A.D. Evidence from stratigraphy radiocarbon dating and magmatic evolution of erupted products. Journal of Volcanology and Geothermal Research, Evaluating Explosive Eruption Risk at European VolcanoesContribution from the EXPLORIS Project 178, 474-490. https://doi.org/10.1016/j.jvolgeores.2008.03.006

Boulanouar, A., Rahmouni, A., Boukalouch, M., Samaouali, A., Géraud, Y., Harnafi, M., Sebbani, J., 2013. Determination of Thermal Conductivity and Porosity of Building Stone from Ultrasonic Velocity Measurements. Geomaterials 03, 138-144. https://doi.org/10.4236/gm.2013.34018 
Bouysse, P., 1983. The Lesser Antilles Island Arc: structure and geodynamic evolution (Service Géologique National). Bureau de Recherches Géologiques et Minières.

Bouysse, P., Westercamp, D., 1990. Subduction of Atlantic aseismic ridges and Late Cenozoic evolution of the Lesser Antilles island arc. Tectonophysics 175, 349-380.

Brehme, M., Moeck, I., Kamah, Y., Zimmermann, G., Sauter, M., 2014. A hydrotectonic model of a geothermal reservoir - A study in Lahendong, Indonesia. Geothermics 51, 228-239. https://doi.org/10.1016/j.geothermics.2014.01.010

Butler, R.F., 1998. Paleomagnetism: Magnetic domains to geologic terranes. Electronic edition 23.

Calcagno, P., Bouchot, V., Thinon, I., Bourgine, B., 2012. A new 3D fault model of the Bouillante geothermal province combining onshore and offshore structural knowledge (French West Indies). Tectonophysics, Modelling in Geosciences 526-529, 185-195. https://doi.org/10.1016/j.tecto.2011.08.012

Cant, J.L., Siratovich, P.A., Cole, J.W., Villeneuve, M.C., Kennedy, B.M., 2018. Matrix permeability of reservoir rocks, Ngatamariki geothermal field, Taupo Volcanic Zone, New Zealand. Geothermal Energy 6, 2. https://doi.org/10.1186/s40517-017-0088-6

Carlut, J., Quidelleur, X., Courtillot, V., Boudon, G., 2000. Paleomagnetic directions and K/Ar dating of 0 to $1 \mathrm{Ma}$ lava flows from La Guadeloupe Island (French West Indies): Implications for time-averaged field models. Journal of Geophysical Research: Solid Earth 105, 835-849. https://doi.org/10.1111/j.1365246X.1971.tb03616.x

Chadima, M., 2011. Application of magnetic susceptibility susceptibility as a function of temperature, field and frequency.

Clauser, C., Huenges, E., 1995. Thermal Conductivity of Rocks and Minerals, in: Ahrens, T.J. (Ed.), Rock Physics \& Phase Relations. American Geophysical Union, pp. 105-126. https://doi.org/10.1029/RF003p0105

Coutant, O., Bernard, M.L., Beauducel, F., Nicollin, F., Bouin, M.P., Roussel, S., 2012. Joint inversion of P-wave velocity and density, application to La Soufrière of Guadeloupe hydrothermal system. Geophys J Int 191, 723-742. https://doi.org/10.1111/j.1365-246X.2012.05644.x

Cox, S.C., Menzies, C.D., Sutherland, R., Denys, P.H., Chamberlain, C., Teagle, D. a. H., 2015. Changes in hot spring temperature and hydrogeology of the Alpine Fault hanging wall, New Zealand, induced by distal South Island earthquakes. Geofluids 15, 216-239. https://doi.org/10.1111/gfl.12093

Cox, S.F., 2010. The application of failure mode diagrams for exploring the roles of fluid pressure and stress states in controlling styles of fracture-controlled permeability enhancement in faults and shear zones. Geofluids 10, 217-233. https://doi.org/10.1111/j.1468-8123.2010.00281.x

Davidson, J., De Silva, S., 2000. Composite volcanoes, in: Encyclopedia of Volcanoes. Haraldur Sigurdsson, p. 1442.

Degraff, J.M., Aydin, A., 1993. Effect of thermal regime on growth increment and spacing of contraction joints in basaltic lava. J. Geophys. Res. 98, 6411-6430. https://doi.org/10.1029/92JB01709

DeMets, C., Jansma, P.E., Mattioli, G.S., Dixon, T.H., Farina, F., Bilham, R., Calais, E., Mann, P., 2000. GPS geodetic constraints on Caribbean-North America Plate Motion. Geophys. Res. Lett. 27, 437-440. https://doi.org/10.1029/1999GL005436

Escartín, J., Leclerc, F., Olive, J.-A., Mevel, C., Cannat, M., Petersen, S., Augustin, N., Feuillet, N., Deplus, C., Bezos, A., Bonnemains, D., Chavagnac, V., Choi, Y., Godard, M., Haaga, K.A., Hamelin, C., Ildefonse, B., Jamieson, J.W., John, B.E., Leleu, T., MacLeod, C.J., Massot-Campos, M., Nomikou, P., Paquet, M., Rommevaux-Jestin, C., Rothenbeck, M., Steinführer, A., Tominaga, M., Triebe, L., Campos, R., Gracias, N., Garcia, R., Andreani, M., Vilaseca, G., 2016. First direct observation of coseismic slip and seafloor rupture along a submarine normal fault and implications for fault slip history. Earth and Planetary Science Letters 450, 96-107. https://doi.org/10.1016/j.epsl.2016.06.024

Farquharson, J., Heap, M.J., Varley, N.R., Baud, P., Reuschle, T., 2015. Permeability and porosity relationships of edifice-forming andesites; a combined field and laboratory study. Journal of Volcanology and Geothermal Research 297, 52-68. https://doi.org/10.1016/j.jvolgeores.2015.03.016

Faulkner, D.R., Jackson, C.A.L., Lunn, R.J., Schlische, R.W., Shipton, Z.K., Wibberley, C.A.J., Withjack, M.O., 2010. A review of recent developments concerning the structure, mechanics and fluid flow properties of fault zones. Journal of Structural Geology, Fault Zones 32, 1557-1575. https://doi.org/10.1016/j.jsg.2010.06.009

Feng, Z., 2008. Volcanic rocks as prolific gas reservoir: A case study from the Qingshen gas field in the Songliao Basin, NE China. Marine and Petroleum Geology, Geology of Giant gas Fields in China 25, 416432. https://doi.org/10.1016/j.marpetgeo.2008.01.008

Feuillet, N., Beauducel, F., Jacques, E., Tapponnier, P., Delouis, B., Bazin, S., Vallée, M., King, G.C.P., 2011. The $\mathrm{Mw}=6.3$, November 21, 2004, Les Saintes earthquake (Guadeloupe): Tectonic setting, slip model and static stress changes. J. Geophys. Res. 116, B10301. https://doi.org/10.1029/2011JB008310 
Feuillet, N., Leclerc, F., Tapponnier, P., Beauducel, F., Boudon, G., Le Friant, A., Deplus, C., Lebrun, J.F., Nercessian, A., Saurel, J.-M., Clément, V., 2010. Active faulting induced by slip partitioning in Montserrat and link with volcanic activity: New insights from the 2009 GWADASEIS marine cruise data. Geophys. Res. Lett. 37, L00E15. https://doi.org/10.1029/2010GL042556

Feuillet, N., Manighetti, I., Tapponnier, P., Jacques, E., 2002. Arc parallel extension and localization of volcanic complexes in Guadeloupe, Lesser Antilles. Journal of Geophysical Research 107. https://doi.org/10.1029/2001JB000308

Gadalia, A., 2013. Exploration géothermique de la zone de Vieux Habitants. Etat des connaissances géologiques. (Rapport d'avancement No. BRGM/RP-62569-FR).

Gailler, L.-S., Bouchot, V., Martelet, G., Thinon, I., Coppo, N., Baltassat, J.-M., Bourgeois, B., 2014. Contribution of multi-method geophysics to the understanding of a high-temperature geothermal province: The Bouillante area (Guadeloupe, Lesser Antilles). Journal of Volcanology and Geothermal Research 275, 34-50. https://doi.org/10.1016/j.jvolgeores.2014.02.002

Gaudin, D., Beauducel, F., Allemand, P., Delacourt, C., Finizola, A., 2013. Heat flux measurement from thermal infrared imagery in low-flux fumarolic zones: Example of the Ty fault (La Soufrière de Guadeloupe). Journal of Volcanology and Geothermal Research 267, 47-56. https://doi.org/10.1016/j.jvolgeores.2013.09.009

Gaudin, D., Beauducel, F., Coutant, O., Delacourt, C., Richon, P., de Chabalier, J.-B., Hammouya, G., 2016. Mass and heat flux balance of La Soufrière volcano (Guadeloupe) from aerial infrared thermal imaging. Journal of Volcanology and Geothermal Research 320, 107-116. https://doi.org/10.1016/j.jvolgeores.2016.04.007

Gaudin, D., Finizola, A., Delcher, E., Beauducel, F., Allemand, P., Delacourt, C., Brothelande, E., Peltier, A., Di Gangi, F., 2015. Influence of rainfalls on heat and steam fluxes of fumarolic zones: Six months records along the Ty fault (Soufrière of Guadeloupe, Lesser Antilles). Journal of Volcanology and Geothermal Research 302, 273-285. https://doi.org/10.1016/j.jvolgeores.2015.06.015

Giesche, H., 2006. Mercury Porosimetry: A General (Practical) Overview. Particle \& Particle Systems Characterization 23, 9-19. https://doi.org/10.1002/ppsc.200601009

Hadi, J., Harrison, C., Keller, J., Rejeki, S., 2005. Overview of Darajat Reservoir Characterization: A Volcanic Hosted Reservoir. Presented at the World Geothermal Congress, Antalya, Turkey, p. 11.

Haffen, S., 2012. Caractéristiques géothermiques du réservoir gréseux du Bundsandstein d'Alsace. Université de Strasbourg, Strasbourg.

Heap, M.J., Farquharson, J.I., Baud, P., Lavallee, Y., Reuschle, T., 2015. Fracture and compaction of andesite in a volcanic edifice. Bulletin of Volcanology 77. https://doi.org/10.1007/s00445-015-0938-7

Heap, M.J., Kennedy, B.M., 2016. Exploring the scale-dependent permeability of fractured andesite. Earth and Planetary Science Letters 447, 139-150. https://doi.org/10.1016/j.eps1.2016.05.004

Heise, W., Caldwell, T.G., Bertrand, E.A., Hill, G.J., Bennie, S.L., Palmer, N.G., 2016. Imaging the deep source of the Rotorua and Waimangu geothermal fields, Taupo Volcanic Zone, New Zealand. Journal of Volcanology and Geothermal Research, The Lake Rotomahana Geothermal System and Effects of the 1886 Mt. Tarawera Eruption 314, 39-48. https://doi.org/10.1016/j.jvolgeores.2015.10.017

Howell, J.A., Martinius, A.W., Good, T.R., 2014. The application of outcrop analogues in geological modelling: a review, present status and future outlook. Geological Society, London, Special Publications 387, SP387.12. https://doi.org/10.1144/SP387.12

Hrouda, F., Buriánek, D., Krejčí, O., Chadima, M., 2015. Magnetic fabric and petrology of Miocene subvolcanic sills and dykes emplaced into the SW Flysch Belt of the West Carpathians (S Moravia, Czech Republic) and their volcanological and tectonic implications. Journal of Volcanology and Geothermal Research 290, 23-38. https://doi.org/10.1016/j.jvolgeores.2014.12.001

Iundt, F., Ouzounian, G., 1985. Comparaison entre les eaux thermales et les fluides de forages géothermiques dans la région de Bouillante (Guadeloupe). (Rapport BRGM No. 85 SGN 351 GTH). BRGM.

Jacques, D., Maury, R., 1988a. Carte géologique à 1/20000, département de la Guadeloupe. BRGM, Service Géologique Nationale, Orléans.

Jacques, D., Maury, R., 1988b. L'archipel des Saintes (Guadeloupe, Petites Antilles): géologie et pétrologie Géologie de la France, 11.

Jacques, D., Maury, R.C., Bellon, H., 1984. Géologie et géochronologie 40K-40Ar des îles des Saintes (Guadeloupe). Comptes-rendus des séances de l'Académie des sciences. Série 2, Mécanique-physique, chimie, sciences de l'univers, sciences de la terre 299, 721-726.

Jamtveit, B., Kobchenko, M., Austrheim, H., Malthe-Sorenssen, A., Royne, A., Svensen, H., 2011. Porosity evolution and crystallization-driven fragmentation during weathering of andesite. Journal of Geophysical Research 116,@CitationB12204-@CitationB12204. https://doi.org/10.1029/2011JB008649 
Jamtveit, B., Malthe-Sorenssen, A., Kostenko, O., 2008. Reaction enhanced permeability during retrogressive metamorphism. Earth and Planetary Science Letters 267, 620-627. https://doi.org/10.1016/j.eps1.2007.12.016

Jamtveit, B., Putnis, C.V., Malthe-Sorenssen, A., 2009. Reaction induced fracturing during replacement processes. Contributions to Mineralogy and Petrology 157, 127-133. https://doi.org/10.1007/s00410-0080324-y

Jelinek, V., 1981. Characterization of the magnetic fabric of rocks. Tectonophysics 79, T63-T67. https://doi.org/10.1016/0040-1951(81)90110-4

Klinkenberg, L.J., 1941. The Permeability Of Porous Media To Liquids And Gases. Presented at the Drilling and Production Practice, American Petroleum Institute.

Komorowski, J.-C., Boudon, G., Michel, S., Beauducel, F., Anténor-Habazac, C., Bazin, S., Hammouya, G., 2005. Guadeloupe, in: Volcanic Hazard Atlas of the Lesser Antilles. Seismic Research Unit, University of the West Indies, p. 279.

Lachassagne, P., Marechal, J.C., Sanjuan, B., 2009. Hydrogeological model of a high-energy geothermal field (Bouillante area, Guadeloupe, French West Indies). Hydrogeol J 17, 1589. https://doi.org/10.1007/s10040-009-0486-3

Leclerc, F., Feuillet, N., Cabioch, G., Deplus, C., Lebrun, J.F., Bazin, S., Beauducel, F., Boudon, G., LeFriant, A., de Min, L., Melezan, D., 2014. The Holocene drowned reef of Les Saintes Plateau as witness of a long-term tectonic subsidence along the Lesser Antilles volcanic arc in Guadeloupe. Marine Geology 355, 115-135. https://doi.org/10.1016/j.margeo.2014.05.017

Leclerc, F., Feuillet, N., Deplus, C., 2016. Interactions between active faulting, volcanism, and sedimentary processes at an island arc: Insights from Les Saintes channel, Lesser Antilles arc. Geochem. Geophys. Geosyst. 17, 2781-2802. https://doi.org/10.1002/2016GC006337

Lenhardt, N., Götz, A.E., 2015. Geothermal reservoir potential of volcaniclastic settings: The Valley of Mexico, Central Mexico. Renewable Energy 77, 423-429. https://doi.org/10.1016/j.renene.2014.12.034

Lenhardt, N., Götz, A.E., 2011. Volcanic settings and their reservoir potential: An outcrop analog study on the Miocene Tepoztlán Formation, Central Mexico. Journal of Volcanology and Geothermal Research 204, 66-75. https://doi.org/10.1016/j.jvolgeores.2011.03.007

Lesparre, N., Boyle, A., Grychtol, B., Cabrera, J., Marteau, J., Adler, A., 2016. Electrical resistivity imaging in transmission between surface and underground tunnel for fault characterization. Journal of Applied Geophysics 128, 163-178. https://doi.org/10.1016/j.jappgeo.2016.03.004

Lopez, S., Lakhssassi, M., Giuglaris, E., 2011. Modeling of Bouillante geothermal field (Guadeloupe, French Lesser Antilles). Presented at the 19ème Conférence Géologique de la Caraïbe.

Manga, M., Hornbach, M.J., Le Friant, A., Ishizuka, O., Stroncik, N., Adachi, T., Aljahdali, M., Boudon, G., Breitkreuz, C., Fraass, A., Fujinawa, A., Hatfield, R., Jutzeler, M., Kataoka, K., Lafuerza, S., Maeno, F., Martinez-Colon, M., McCanta, M., Morgan, S., Palmer, M.R., Saito, T., Slagle, A., Stinton, A.J., Subramanyam, K.S.V., Tamura, Y., Talling, P.J., Villemant, B., Wall-Palmer, D., Wang, F., 2012. Heat flow in the Lesser Antilles island arc and adjacent back arc Grenada basin. Geochem. Geophys. Geosyst. 13, Q08007. https://doi.org/10.1029/2012GC004260

Mas, A., Guisseau, D., Patrier Mas, P., Beaufort, D., Genter, A., Sanjuan, B., Girard, J.P., 2006. Clay minerals related to the hydrothermal activity of the Bouillante geothermal field (Guadeloupe). Journal of Volcanology and Geothermal Research 158, 380-400. https://doi.org/10.1016/j.jvolgeores.2006.07.010

Massiot, C., Nicol, A., Townend, J., McNamara, D.D., Garcia-Sellés, D., Conway, C.E., Archibald, G., 2017. Quantitative geometric description of fracture systems in an andesite lava flow using terrestrial laser scanner data. Journal of Volcanology and Geothermal Research 341, 315-331. https://doi.org/10.1016/j.jvolgeores.2017.05.036

Mathieu, L., 2010. The structure of Guadeloupe, Maderas and Mt Cameroon volcanoes and the impact of strike-slip movements. Université Blaise Pascal - Clermont Ferrand II; Trinity College Dublin.

McNamara, D.D., Sewell, S., Buscarlet, E., Wallis, I.C., 2016. A review of the Rotokawa Geothermal Field, New Zealand. Geothermics, Taupo Volcanic Zone Geothermal Systems, New Zealand : Exploration, Science and Development 59, 281-293. https://doi.org/10.1016/j.geothermics.2015.07.007

Micklethwaite, S., Ford, A., Witt, W., Sheldon, H.A., 2015. The where and how of faults, fluids and permeability - insights from fault stepovers, scaling properties and gold mineralisation. Geofluids 15, 240251. https://doi.org/10.1111/gfl.12102

Mielke, P., Bär, K., Sass, I., 2017. Determining the relationship of thermal conductivity and compressional wave velocity of common rock types as a basis for reservoir characterization. Journal of Applied Geophysics 140, 135-144. https://doi.org/10.1016/j.jappgeo.2017.04.002

Mielke, P., Nehler, M., Bignall, G., Sass, I., 2015. Thermo-physical rock properties and the impact of 
advancing hydrothermal alteration - A case study from the Tauhara geothermal field, New Zealand. Journal of Volcanology and Geothermal Research 301, 14-28. https://doi.org/10.1016/j.jvolgeores.2015.04.007

Mielke, P., Weinert, S., Bignall, G., Sass, I., 2016. Thermo-physical rock properties of greywacke basement rock and intrusive lavas from the Taupo Volcanic Zone, New Zealand. Journal of Volcanology and Geothermal Research 324, 179-189. https://doi.org/10.1016/j.jvolgeores.2016.06.002

Millot, R., Scaillet, B., Sanjuan, B., 2010. Lithium isotopes in island arc geothermal systems: Guadeloupe, Martinique (French West Indies) and experimental approach. Geochimica et Cosmochimica Acta 74, 18521871. https://doi.org/10.1016/j.gca.2009.12.007

Moeck, I.S., 2014. Catalog of geothermal play types based on geologic controls. Renewable and Sustainable Energy Reviews 37, 867-882. https://doi.org/10.1016/j.rser.2014.05.032

Morgan, S., Jones, R., Conner, J., Student, J., Schaner, M., Horsman, E., Blanquat, M. de S., 2017. Magma sheets defined with magnetic susceptibility in the Maiden Creek sill, Henry Mountains, Utah, USA. Geology 45, 599-602. https://doi.org/10.1130/G38932.1

Munch, P., Cornee, J.-J., Lebrun, J.-F., Quillevere, F., Verati, C., Melinte-Dobrinescu, M., Demory, F., Smith, B., Jourdan, F., Lardeaux, J.-M., De Min, L., Leticee, J.-L., Randrianasolo, A., 2014. Pliocene to Pleistocene vertical movements in the forearc of the Lesser Antilles subduction: insights from chronostratigraphy of shallow-water carbonate platforms (Guadeloupe archipelago). Journal of the Geological Society 171, 329-341. https://doi.org/10.1144/jgs2013-005

Murphy, H., Huang, C., Dash, Z., Zyvoloski, G., White, A., 2004. Semianalytical solutions for fluid flow in rock joints with pressure-dependent openings. Water Resources Research 40. https://doi.org/10.1029/2004WR003005

Ólavsdóttir, J., Andersen, M.S., Boldreel, L.O., 2015. Reservoir quality of intrabasalt volcaniclastic units onshore Faroe Islands, North Atlantic Igneous Province, northeast Atlantic. AAPG Bulletin 99, 467-497. https://doi.org/10.1306/08061412084

Panaiotu, C., Necula, C., Merezeanu, T., Panaiotu, A., Corban, C., 2011. Anisotropy of magnetic susceptibility of quaternary lava flows from the east Carpathians. Romanian Reports in Physics 63, 526-534.

Pape, H., Clauser, C., Iffland, J., 1999. Permeability prediction based on fractal pore-space geometry. Geophysics 64, 1447-1460. https://doi.org/10.1190/1.1444649

Patrier, P., Beaufort, D., Mas, A., Traineau, H., 2003. Surficial clay assemblage associated with the hydrothermal activity of Bouillante (Guadeloupe, French West Indies). Journal of Volcanology and Geothermal Research 126, 143-156. https://doi.org/10.1016/S0377-0273(03)00133-1

Patrier, P., Bruzac, S., Pays, R., Beaufort, D., Bouchot, V., Verati, C., Gadalia, A., 2013. Occurrence of K-feldspar-bearing hydrothermal breccias in the Bouillante geothermal field (Basse Terre - Guadeloupe). Bulletin de la Société Géologique de France 184, 119-128. https://doi.org/10.2113/gssgfbull.184.1-2.119

Peccerillo, A., Taylor, S.R., 1976. Geochemistry of eocene calc-alkaline volcanic rocks from the Kastamonu area, Northern Turkey. Contr. Mineral. and Petrol. 58, 63-81. https://doi.org/10.1007/BF00384745

Pinti, D.L., Castro, M.C., Lopez-Hernandez, A., Han, G., Shouakar- Stash, O., Hall, C.M., RamírezMontes, M., 2017. Fluid circulation and reservoir conditions of the Los Humeros Geothermal Field (LHGF), Mexico, as revealed by a noble gas survey. Journal of Volcanology and Geothermal Research 333-334, 104115. https://doi.org/10.1016/j.jvolgeores.2017.01.015

Pola, A., Crosta, G., Fusi, N., Barberini, V., Norini, G., 2012. Influence of alteration on physical properties of volcanic rocks. Tectonophysics 566-567, 67-86. https://doi.org/10.1016/j.tecto.2012.07.017

Pola, A., Crosta, G.B., Fusi, N., Castellanza, R., 2014. General characterization of the mechanical behaviour of different volcanic rocks with respect to alteration. Engineering Geology 169, 1-13. https://doi.org/10.1016/j.enggeo.2013.11.011

Popov, Y.A., Beardsmore, G., Clauser, C., Roy, S., 2016. ISRM Suggested Methods for Determining Thermal Properties of Rocks from Laboratory Tests at Atmospheric Pressure. https://doi.org/10.1007/s00603016-1070-5

Popov, Y.A., Pribnow, D.F.C., Sass, J.H., Williams, C.F., Burkhardt, H., 1999. Characterization of rock thermal conductivity by high-resolution optical scanning. Geothermics 28, 253-276. https://doi.org/10.1016/S0375-6505(99)00007-3

Pozzi, J.-P., Le Mouel, J.-L., Rossignol, J.C., Zlotnicki, J., 1979. Magnetic observations made on la soufriere volcano (guadeloupe) during the 1976-1977 crisis. Journal of Volcanology and Geothermal Research 5, 217-237. https://doi.org/10.1016/0377-0273(79)90017-9

Ratouis, T.M.P., Zarrouk, S.J., 2016. Factors controlling large-scale hydrodynamic convection in the Taupo Volcanic Zone (TVZ), New Zealand. Geothermics, Taupo Volcanic Zone Geothermal Systems, New Zealand: Exploration, Science and Development 59, 236-251. 
https://doi.org/10.1016/j.geothermics.2015.09.003

Rejeki, S., Hadi, J., Suhayati, I., 2005. Porosity Study for Detail Reservoir Characterization in Darajat Geothermal Field, West Java, Indonesia. Proceedings, World Geothermal Congress, Antalya, Turkey.

Ricci, J., Lahitte, P., Quidelleur, X., 2015a. Construction and destruction rates of volcanoes within tropical environment: Examples from the Basse-Terre Island (Guadeloupe, Lesser Antilles). Geomorphology 228, 597-607. https://doi.org/10.1016/j.geomorph.2014.10.002

Ricci, J., Quidelleur, X., Lahitte, P., 2015b. Volcanic evolution of central Basse-Terre Island revisited on the basis of new geochronology and geomorphology data. Bull Volcanol 77, 84. https://doi.org/10.1007/s00445-015-0970-7

Ricci, J., Quidelleur, X., Pallares, C., Lahitte, P., 2017. High-resolution K-Ar dating of a complex magmatic system: The example of Basse-Terre Island (French West Indies). Journal of Volcanology and Geothermal Research. https://doi.org/10.1016/j.jvolgeores.2017.07.013

Roduit, N., 2007. JMicroVision : un logiciel d'analyse d'images pétrographiques polyvalent. University of Geneva.

Rosas-Carbajal, M., Komorowski, J.-C., Nicollin, F., Gibert, D., 2016. Volcano electrical tomography unveils edifice collapse hazard linked to hydrothermal system structure and dynamics. Scientific Reports 6 , 29899. https://doi.org/10.1038/srep29899

Rosener, M., 2007. Etude pétrophysique et modélisation des effets des transferts thermiques entre roche et fluide dans le contexte géothermique de Soultz-sous-Forêts. Strasbourg 1.

Rowland, J.V., Sibson, R.H., 2004. Structural controls on hydrothermal flow in a segmented rift system, Taupo Volcanic Zone, New Zealand. Geofluids 4, 259-283. https://doi.org/10.1111/j.14688123.2004.00091.x

Rowland, J.V., Simmons, S.F., 2012. Hydrologic, Magmatic, and Tectonic Controls on Hydrothermal Flow, Taupo Volcanic Zone, New Zealand: Implications for the Formation of Epithermal Vein Deposits. Economic Geology 107, 427-457. https://doi.org/10.2113/econgeo.107.3.427

Sak, P.B., Navarre-Sitchler, A.K., Miller, C.E., Daniel, C.C., Gaillardet, J., Buss, H.L., Lebedeva, M.I., Brantley, S.L., 2010. Controls on rind thickness on basaltic andesite clasts weathering in Guadeloupe. Chemical Geology 276, 129-143. https://doi.org/10.1016/j.chemgeo.2010.05.002

Samper, A., 2007. Etude géochronologique, aspects géomorphologiques et géochimiques du volcanisme de l'île de Basse Terre (Guadeloupe), et datation des structures d'effondrement de flanc majeures de l'arc des Petites Antilles. Université de Paris-Sud. Faculté des Sciences d'Orsay (Essonne).

Samper, A., Quidelleur, X., Komorowski, J.-C., Lahitte, P., Boudon, G., 2009. Effusive history of the Grande Découverte Volcanic Complex, southern Basse-Terre (Guadeloupe, French West Indies) from new KAr Cassignol-Gillot ages. Journal of Volcanology and Geothermal Research 187, 117-130. https://doi.org/10.1016/j.jvolgeores.2009.08.016

Samper, A., Quidelleur, X., Lahitte, P., Mollex, D., 2007. Timing of effusive volcanism and collapse events within an oceanic arc island: Basse-Terre, Guadeloupe archipelago (Lesser Antilles Arc). Earth and Planetary Science Letters 258, 175-191. https://doi.org/10.1016/j.eps1.2007.03.030

Sanjuan, B., Brach, M., 2015. Geochemical Monitoring of the Thermal Manifestations Located Near the Bouillante Geothermal Power Plant, in Guadeloupe (FWI). Procedia Earth and Planetary Science, 11th Applied Isotope Geochemistery Conference AIG-11 13, 25-29. https://doi.org/10.1016/j.proeps.2015.07.006

Sanjuan, B., Brach, M., 1998. Etude hydrogéochimique du champ géothermique de Bouillante (Guadeloupe) (Rapport BRGM No. 39880). BRGM.

Sanjuan, B., Brach, M., Lasne, E., 2001. Bouillante geothermal field: mixing and water/rock interaction processes at $250^{\circ}$ C., in: Cidu, R. (Ed.), Water Rock Interaction, WRI-10, International Symposium on Water Rock Interaction. A.A. Balkema Publishers, Villasimius, Italy, pp. 911-914.

Sanjuan, B., Jousset, P., Pajot, G., Debeglia, N., Michele, M.D., Brach, M., Dupont, F., Braibant, G., Lasne, E., Duré, F., 2010. Monitoring of the Bouillante Geothermal Exploitation (Guadeloupe, French West Indies) and the Impact on Its Immediate Environment. Presented at the World Geothermal Congress 2010, p. $11 \mathrm{p}$.

Sanjuan, B., Lasne, E., Brach, M., 2000. Bouillante Geothermal Field (Guadeloupe, West Indies): Geochemical monitoring during a thermal simulation operation. Presented at the Workshop on Geothermal Reservoir Engineering, Stanford, p. 8.

Sanjuan, B., Le Nindre, Y.-M., Menjoz, A., Sbai, A., Brach, M., Lasne, E., 2004. Travaux de recherche liés au développement du champ géothermique de Bouillante (Guadeloupe) (Rapport BRGM No. RP-53136FR). BRGM.

Sanjuan, B., Traineau, H., 2008. Development of the Bouillante geothermal field (Guadeloupe, French West Indies). IGA News Quaterly n73, 5-9. 
Schön, Juergen H., 2015. Physical Properties of Rocks: Fundamentals and Principles of Petrophysics. Elsevier.

Scibek, J., Gleeson, T., McKenzie, J.M., 2016. The biases and trends in fault zone hydrogeology conceptual models: global compilation and categorical data analysis. http://dx.doi.org/10.1111/gfl.12188

Sibson, R.H., 1996. Structural permeability of fluid-driven fault-fracture meshes. Journal of Structural Geology 18, 1031-1042. https://doi.org/10.1016/0191-8141(96)00032-6

Sibson, R.H., 1994. Crustal stress, faulting and fluid flow. Geological Society, London, Special Publications 78, 69-84. https://doi.org/10.1144/GSL.SP.1994.078.01.07

Sibson, R.H., Rowland, J.V., 2003. Stress, fluid pressure and structural permeability in seismogenic crust, North Island, New Zealand. Geophys J Int 154, 584-594. https://doi.org/10.1046/j.1365-246X.2003.01965.x

Simpson, M.P., Bignall, G., 2016. Undeveloped high-enthalpy geothermal fields of the Taupo Volcanic Zone, New Zealand. Geothermics, Taupo Volcanic Zone Geothermal Systems, New Zealand: Exploration, Science and Development 59, 325-346. https://doi.org/10.1016/j.geothermics.2015.08.006

Siratovich, P., Heap, M.J., Villeneuve, M., W Cole, J., Reuschlé, T., 2014. Physical property relationships of the Rotokawa Andesite, a significant geothermal reservoir rock in the Taupo Volcanic Zone, New Zealand. Geothermal Energy 1, 10. https://doi.org/10.1186/s40517-014-0010-4

Sizun, J.-P., 1995. Modifications des structures de porosite de gres lors de transformations petrographiques dans la diagenese et l'hydrothermalisme: application au trias de la marge ardechoise et du fosse rhenan. Strasbourg 1.

Stanek, M., 2013. Structural and petrophysical characterisation of granite : intended for radioactive waste stocking. Strasbourg.

Stimac, J.A., Powell, T.S., Golla, G.U., 2004. Porosity and permeability of the Tiwi geothermal field, Philippines, based on continuous and spot core measurements. Geothermics, Philippine Geothermal Systems Response to Production 33, 87-107. https://doi.org/10.1016/j.geothermics.2003.03.002

Surma, F., Geraud, Y., 2003. Porosity and Thermal Conductivity of the Soultz-sous-Forêts Granite. Pure appl. geophys. 160, 1125-1136. https://doi.org/10.1007/PL00012564

Symithe, S., Calais, E., de Chabalier, J.B., Robertson, R., Higgins, M., 2015. Current block motions and strain accumulation on active faults in the Caribbean. J. Geophys. Res. Solid Earth 120, 2014JB011779. https://doi.org/10.1002/2014JB011779

Tardani, D., Reich, M., Roulleau, E., Takahata, N., Sano, Y., Pérez-Flores, P., Sánchez-Alfaro, P., Cembrano, J., Arancibia, G., 2016. Exploring the structural controls on helium, nitrogen and carbon isotope signatures in hydrothermal fluids along an intra-arc fault system. Geochimica et Cosmochimica Acta 184, 193-211. https://doi.org/10.1016/j.gca.2016.04.031

Thinon, I., Guennoc, P., Bitri, A., Truffert, C., 2010. Study of the Bouillante Bay (West Basse-Terre Island shelf): contribution of geophysical surveys to the understanding of the structural context of Guadeloupe (French West Indies-Lesser Antilles). Bulletin de la Société géologique de France 181, 51-65.

Traineau, H., Sanjuan, B., Lasne, E., 2014. Main results of a long-term monitoring of the Bouillante geothermal reservoir during its exploitation. Presented at the Deep Geothermal Days.

Vallance, J.W., Iverson, R.M., 2015. Chapter 37 - Lahars and Their Deposits. The Encyclopedia of Volcanoes 649-664.

Verati, C., Mazabraud, Y., Lardeaux, J.-M., Corsini, M., Schneider, D., Voitus, E., Zami, F., 2016. Tectonic evolution of Les Saintes Archipelago (Guadeloupe, French West Indies); relation with the Lesser Antilles arc system. Bulletin de la Societe Geologique de France 187, 3-10. https://doi.org/10.2113/gssgfbull.187.1.3

Verati, C., Patrier-Mas, P., Lardeaux, J.M., Bouchot, V., 2013. Timing of geothermal activity in an active island-arc volcanic setting; first (super 40) Ar/ (super 39) Ar dating from Bouillante geothermal field (Guadeloupe, French West Indies). Special Publication - Geological Society of London 378. https://doi.org/10.1144/SP378.19

Wang, P., Chen, S., 2015. Cretaceous volcanic reservoirs and their exploration in the Songliao Basin, northeast China. AAPG Bulletin 99, 499-523. https://doi.org/10.1306/09041413095

Washburn, E.W., 1921. The Dynamics of Capillary Flow. Phys. Rev. 17, 273-283. https://doi.org/10.1103/PhysRev.17.273

Wilmarth, M., Stimac, J., 2015. Power density in geothermal fields, in: Proceedings. Presented at the World Geothermal Congress, Melbourne, Australia, p. 7.

Wilson, C.J.N., Rowland, J.V., 2016. The volcanic, magmatic and tectonic setting of the Taupo Volcanic Zone, New Zealand, reviewed from a geothermal perspective. Geothermics, Taupo Volcanic Zone Geothermal Systems, New Zealand: Exploration, Science and Development 59, 168-187. https://doi.org/10.1016/j.geothermics.2015.06.013 
Wyering, L.D., Villeneuve, M., Wallis, I., Siratovich, P., Kennedy, B., Gravley, D.M., Cant, J.L., 2014. Mechanical and physical properties of hydrothermally altered rocks, Taupo Volcanic Zone, New Zealand. Journal of Volcanology and Geothermal Research 288. https://doi.org/10.1016/j.jvolgeores.2014.10.008

Yi, J., Wang, P., Gao, Y., Yao, R., Zhao, R., Chen, C., 2015. Vesicle distribution in basalt lava flow units in the Mesozoic rift basins of northeast China and its application in gas reservoir prediction. Can. J. Earth Sci. 53, 59-70. https://doi.org/10.1139/cjes-2015-0004

Zami, F., Quidelleur, X., Ricci, J., Lebrun, J.-F., Samper, A., 2014. Initial sub-aerial volcanic activity along the central Lesser Antilles inner arc: New $\mathrm{K}-\mathrm{Ar}$ ages from Les Saintes volcanoes. Journal of Volcanology and Geothermal Research 287, 12-21. https://doi.org/10.1016/j.jvolgeores.2014.09.011 